\title{
State Discriminations Against Interstate Commerce
}

\author{
Michael E. Smith†
}

In recent years the Supreme Court has invalidated an unusually large number of state regulations as improper interferences with interstate commerce. ${ }^{1}$ Since 1976 there have been at least ten decisions to this effect accoinpamied by full opimons. ${ }^{2}$ To find another ten such decisions we may have to go back as far as $1941 .^{3}$

It is conventional to divide state interferences with interstate commerce according to their subject inatter- "incoming coinmerce," "outgoing cominerce," "transportation," and so forth. ${ }^{4}$ The division may have made sense at one tiine, when there were special doctrines relating to the importation of harmful goods, ${ }^{5}$ the exportation of natural resources, ${ }^{6}$ and the like. Of late, however, these subject inatter doctrines have largely disintegrated. ${ }^{7}$

$\dagger$ Professor of Law, Boalt Hall School of Law, University of California, Berkeley. B.A. 1956, Haverford College; M.A. 1963, Harvard University; J.D. 1964, University of Michigan.

The practice of acknowledging help in the writing of insignificant law review articles has gotten out of hand; otherwise the author would note his exceptional indebtedness to Professor Robert C. Post.

1. Professor Eule may have been the first to recognize this trend. See Eule, Laying the Dormant Commerce Clause to Rest, 91 YALE L.J. 425 (1982).

2. Sporhase v. Nebraska ex rel. Douglas, 458 U.S. 941 (1982); Edgar v. MITE Corp., 457 U.S. 624 (1982); New England Power Co. v. New Hampshire, 455 U.S. 331 (1982); Kassel v. Consolidated Freightways Corp., 450 U.S. 662 (1981); Lewis v. BT Inv. Managers, 447 U.S. 27 (1980); Hughes v. Oklahoma, 441 U.S. 322 (1979); City of Philadelphia v. New Jersey, 437 U.S. 617 (1978); Raymond Motor Transp., Inc. v. Rice, 434 U.S. 429 (1978); Hunt v. Washington Apple Advertising Comm'n, 432 U.S. 333 (1977); Great Atl. \& Pac. Tea Co. v. Cottrell, 424 U.S. 366 (1976).

3. Allenberg Cotton Co. v. Pittman, 419 U.S. 20 (1974); Pike v. Bruce Church, Inc., 397 U.S. 137 (1970); Polar Ice Cream \& Creamery Co. v. Andrews, 375 U.S. 361 (1964); Bibb v. Navajo Freight Lines, 359 U.S. 520 (1959); Dean Milk Co. v. City of Madison, 340 U.S. 349 (1951); H.P. Hood \& Sons v. Du Mond, 336 U.S. 525 (1949); Toomer v. Witsell, 334 U.S. 385 (1948); Morgan v. Virginia, 328 U.S. 373 (1946); Southern Pac. Co. v. Arizona ex rel. Sullivan, 325 U.S. 761 (1945); Edwards v. California, 314 U.S. 160 (1941).

4. E.g., G. Gunther, Cases and Materials ON Constitutional Law 271-341 (10th ed. 1980); W. Lockhart, Y. Kamisar \& J. ChOpER, CONSTITUTIONAL Law 293-335 (5th ed. 1980); J. Nowak, R. Rotunda \& J. Young, Constitutional LaW 275-91 (2d ed. 1983); L. TRibe, AMERICAN CONSTTUUTIONAL LAW 328-35 (1978).

5. See Baldwin v. G.A.F. Seelig, 1nc., 294 U.S. 511, 525 (1935) and cases cited therein.

6. Hudson County Water Co. v. McCarter, 209 U.S. 349 (1908); Geer v. Connecticut, 161 U.S. 519 (1896).

7. Hughes v. Oklahoma, 441 U.S. 322 (1979); City of Philadelphia v. New Jersey, 437 U.S. 617 (1978). 
They have been replaced by a pervasive dichotomy between state regulations that discriminate against interstate commerce and those that do not. The nub of the matter is that discriminatory regulations are almost invariably invalid, whereas nondiscriminatory regulations are much more likely to survive.

The subject of this Article is thoroughly conventional, a description of present Supreme Court doctrine concerning discriminatory state regulations. I take the Court's decisions as my starting point-not just the results of the decisions but the rules that the Court purports to follow and the reasons that it gives for these rules. I will identify the doctrines that account for the great majority of the decisions, acknowledging that the remnant are aberrant. I will attempt to integrate the doctrines into a coherent structure and to relate them to the Court's premises. For the sake of comprehensiveness, I will also point out the unsettled areas of the subject.

The purpose of this enterprise is also conventional. There are still practitioners of the law-judges, legislators, and administrators, counselors at law, and even teachers-who are convinced that legal doctrine exists and that adhering to existing doctrine is a primary legal value. There are plenty of writings to tell these people what doctrines ought to govern the subject of state interference with interstate commerce but few that describe for them existing doctrine and perhaps none that do so comprehensively and cogently. This Article attempts to meet their need. ${ }^{8}$

Some readers may suppose that the project is futile, that the law concerning state interference with interstate commerce is irretrievably incoherent. The classic expression of this view is the satirical restatement of the law of interstate commerce of a generation ago:

Although the power of the Federal Government over interstate commerce is plenary, the states may regulate commerce some, but not too much. If a state attempts to regulate commerce too much such regulation will be unconstitutional. Caveat: This Restatement is not intended to express any opinion as to how much regulation is too much. ${ }^{9}$

The criticism was later taken up by the Supreme Court itself. In the leading case of Prudential Insurance Co. v. Benjamin, ${ }^{10}$ Justice Rutledge wrote for the Court that the commerce clause "is not the simple, clean-

8. Regan, The Supreme Court and State Protectionism: Making Sense of the Dormant Commerce Clause, 84 MiCH. L. REv. 1091 (1986), the most penetrating of the recent articles, is primarily prescriptive. Indeed, Professor Regan mistakenly cites this Article as support for his cause. Id. at 1093 n.3. At the same time, Professor Regan's understanding of much of current doctrine is strikingly similar to mine. $I d$. at 1206-87. I have not thought it worthwhile to crossreference our agreements and disagreements.

9. W. Lockhart, Y. Kamisar \& J. Choper, Constitutional. Law 349 (4th ed. 1975).

10. 328 U.S. 408 (1946). 
cutting tool supposed. ... [I]ts implied negative operation on state power has been uneven, at times highly variable. .. [ [T] he history of the commerce clause has been one of very considerable judicial oscillation." "11

Some readers, sharing the outlook of Professors Dowling and Gunther, ${ }^{12}$ may formulate the objection a little differently. They may contend that the Court decides these cases, not according to any structure of doctrine, but by an amorphous balancing process. That is, the Justices take all relevant circumstances into account and render judgment according to their overall sense of the advantages and disadvantages of upholding the regulation. From this viewpoint, there is no clear dichotomy between state regulations that discriminate against interstate commerce and those that do not. They are all tested in approximately the same way.

Ultimately it is a question of degree. Imbued with legal reahisin, we no longer suppose that legal doctrines can be so precise as to leave no rooin for judgment, that everything said in every case will be perfectly consistent. We realize that every legal value eventually conflicts with others and must be balanced against thein. Yet many of us are still convinced that legal doctrines may achieve a significant degree of precision, consistency, and structure. This Article contends that the Supreine Court's rules concerning state discrimination against interstate commerce are reasonably clear; that they fit together and rest on tenable reasons; and that they have produced reasonably uniforin results.

Discriminatory state regulations may be attacked on the basis of numerous provisions of the United States Constitution, including the coinmerce clause, the privileges and immunities clause of article IV, and the equal protection clause. This Article only concerns attacks based on the commerce clause. From time to time, however, doctrine under other clauses will be brought to bear by way of comparison. ${ }^{13}$

I will concentrate on the "current" era, beginning in the middle 1930's with the leading case of Baldwin v. G.A.F. Seelig, Inc. ${ }^{14}$ Baldwin was a major step in the movement away from the older, special doctrines based on subject matter toward the present pervasive distinction between discriminatory and nondiscriminatory regulations. The decision also initiated the abandoument of other older doctrines, such as the conceptual distinction between interstate and imtrastate commerce and between

11. Id. at $418-20$.

12. G. GUNTHER, supra note 4, at 297-341; Dowling, Interstate Commerce and State Power, 27 VA. L. REV. 1, 16 (1940).

13. The scope of this Article is limited in other ways worth mentioning. It refers only in passing to kinds of state action besides regulation, such as taxation, and to discrimination against foreign commerce. It also does not cover state regulation of liquor, which has a special standing under the twenty-first amendment.

14. 294 U.S. 511 (1935). 
direct and indirect impacts on interstate commerce. Consequently, except for a handful of classics, the current Court hardly ever relies on decisions on this subject prior to Baldwin.

Part I of this Article describes the considerations underlying present Supreme Court doctrine. That is, it recites the three reasons that the Court gives for disfavoring discriminations against interstate commerce and two of the Court's contrary concerns. Although these underlying considerations are important in shaping doctrine, by themselves they do not give much guidance in deciding specific issues.

Part II deals with the Supreme Court's definition of discrimination generally. It starts with a proposed defimition and describes in detail the two key concepts. It then speculates on four unsettled issues, the resolution of which might expand or contract the proposed definition.

Part III deals with the legal consequences of discrimmation generally. It shows the heavy burden on the states to justify a discriminatory regulation and describes in detail the three elements of the burden. It also points out the only circuinstance in which the states may avoid this burden.

Part IV reconsiders the subjects of Parts II and III in relation to three specific types of discrimination-on the face of the regulation, in purpose, and in effect. That is, it defines these types and describes the legal consequences of each. Here, too, there are important, unsettled issues on which this Article speculates.

The Article ends with the recitation of a common objection to the foregoing, and iny response. The gist of the dissent is that the Supreme Court decides cases imvolving state discriminations, not according to the structure of doctrine described, but by an amorphous balancing test.

\section{I UNDERLYING CONSIDERATIONS}

Not only does the Supreme Court strongly disfavor state discriminations against interstate commerce; from the start of the current period it has given tenable reasons for doing so. The main reasons are adherence to the intentions of the Frainers, fear of the economic and political consequences of interstate hostihty, and concern about biased local political processes. There are also important concerns pressing in the opposite direction agamst the invalidity of all state discriminations. According to the Court's opimions, these include our traditions of state independence and the limits of judicial competence. On account of the variousness and indeterminacy of these considerations, it is difficult to derive specific rules from them. 


\section{A. Reasons for Disfavoring Discrimination}

\section{Intent of the Framers}

One reason for disfavoring discriminations against interstate commerce rests on what current commentators call an "intepretivist" view of the Constitution. That is, it was the intention of those who adopted the commerce clause to disfavor such discriminations. Thus, in Baldwin $v$. G.A.F. Seelig, Inc., Justice Cardozo stated tersely, "We are reminded in the opinion below [by Judge Learned Hand] that a chief occasion of the commerce clauses was the mutual jealousies and aggressions of the States, taking form in customs barriers and other economic retaliation." "15 Justice Jackson elaborated on the point in H.P. Hood \& Sons $v$. $D u$ Mond ${ }^{16}$ in a long passage which began:

When victory relieved the Colonies from the pressure for solidarity that war had exerted, a drift toward anarchy and commercial warfare between the states began. "... each State would legislate according to its estimate of its own interests, the importance of its own products, and the local advantages or disadvantages of its position in a political or commercial view." This came "to tlireaten at once the peace and safety of the Union." 17

Neither Justice Cardozo nor Jackson gave examples of state legislation with which the Framers were supposedly concerned, but both cited historical sources that contam such examples. Not surprisingly, the sources referred to James Madison's views more often than those of any other Framer. Madison was most concerned that states having ports through which foreign commerce flowed were taxing imports and exports to enrich their treasuries, at the expense of the people of other states in which the goods originated or for which they were destined. ${ }^{18}$ Madison and others also noted that some states were chagrined about the navigation laws of other states-regulations that made it more difficult for ships to use the ports of a state if the ships were owned by outsiders. ${ }^{19}$ Others were also concerned about entrance and clearance fees assessed against ships using the ports of a state in the course of interstate voyages. ${ }^{20}$

Each of these examples gave rise to constitutional prohibitions more specific than the commerce clause. Article I, section 10, narrowly restricts the power of the states to tax imports and exports and foreign

15. Id. at 522 .

16. 336 U.S. 525 (1949).

17. Id. at 533 (quoting $1 \mathrm{~J}$. STORY, COMMENTARIES ON THE CONSTITUTION OF THE UNITED STATES $\S \S 259-260$ (1833)).

18. The Federalist No. 42, at 274 (J. Madison) (E.M. Earle ed. 1937); 3 M. FARRAND, The Records of the Federal Convention 478, 547-48 (1911).

19. 3 M. FARRAND, supra note 18 , at 548 .

20. C. WARRen, The Making of the Constitution 567 (1929). 
shipping, and the preceding section inhibits Congress from requiring the payment to states of entrance and clearance fees and duties. Nevertheless, these examples indicate the kind of state regulations at which the Supreme Court thinks the more general terms of the commerce clause were aimed.

Most of these early state laws apparently put greater economic burdens on people outside the state to the economic advantage of those within. For example, New York imposed entrance and clearance fees on ships bound from and to Connecticut and New Jersey but apparently not on ships voyaging withm the state. ${ }^{21}$ These fees necessarily tended to make it more expensive for New Yorkers to do business with people in other states than with each other.

\section{Interstate Reprisals}

Justices Cardozo and Jackson also described substantive concerns that justify the Supreme Court's opposition to discrimmatory state regulations. One concern is econormic: state discriminations jeopardize national prosperity by fragmenting the national market. They interfere with the flow of goods and services to places in our nation where they can be used most efficiently. Another concern is political: state discriminations arouse hostility im other states whose inhabitants are victims of the practice. They thereby tend toward interstate strife and disunity. Justice Cardozo summarized these points when he asserted, "The Constitution was framed ... upon the theory ... that in the long run prosperity and salvation are in union and not division." 22 Likewise, Justice Jackson claimed that by checking state regulations affecting comnerce, "this Court has advanced the solidarity and prosperity of this Nation . . .."23

Neither of these quotations explicitly singles out discriminatory regulations as harmful to national prosperity and harmony. Indeed, any substantial state interference with interstate conimerce may fragment the national market and even strain interstate relations. However, discriminatory regulations are thought to be particularly harmful, for they arouse greater anger in other states and lead to retaliatory measures. Thus, Justice Cardozo warned, "If New York, in order to promote the economic welfare of her farmers, may guard them against competition with the cheaper prices of Vermont, the door has been opened to rivalries and reprisals that were meant to be averted by subjecting conmierce between the states to the power of the nation."24 Justice Jackson echoed the warning in a long passage which began, "We need only consider the con-

21. Id. at $567 \mathrm{n} .1$.

22. Baldwin, 294 U.S. at 523.

23. H.P. Hood \& Sons v. Du Mond, 336 U.S. 525, 535 (1949).

24. Baldwin, 294 U.S. at 522. 
sequences if each of the few states that produce copper, lead, high-grade iron ore, timber, cotton, oil or gas should decree that industries located in that state should have priority. What fantastic rivalries and dislocations and reprisals would ensue if such practices were begun!"25 The Supreme Court has often repeated the former passage in later opinions. ${ }^{26}$

\section{3. $\quad$ Biased Political Processes}

Another early leading case introduced the last of the Supreme Court's reasons for disfavoring discriminatory state regulations-the concern that such regulations are the product of political processes in which those inamly burdened are inadequately represented. In South Carolina Highway Department v. Barnwell Bros., ${ }^{27}$ in the first of three famous passages written in the same terin on the same theine, ${ }^{28}$ Justice Stone argued that:

Underlying the stated rule [against discriminatory regulations] has been the thought, often expressed in judicial opinion, that when the regulation is of such a character that its burden falls principally upon those without the state, legislative action is not likely to be subjected to those political restraints which are normally exerted on legislation where it affects adversely some interests within the state. ${ }^{29}$

Stone later apphed this analysis to the facts of the case: "The fact that [the present regulations] affect alike shippers in interstate and intrastate commerce in large number within as well as witlout the state is a safeguard against their abuse." 30

After a short period of repetition, ${ }^{31}$ this justification for disfavoring discriminations fell into disuse by the Supreine Court. Lately, however, it has becoine a favorite of commentators of varying constitutional views, includimg Deans Choper and Ely and Professors Tribe and Tushnet. ${ }^{32}$ Perhaps under their influence, the Court has begun resorting to this justi-

25. Hood, 336 U.S. at 538-39.

26. E.g., Great Atl. \& Pac. Tea Co. v. Cottrell, 424 U.S. 366, 380-81 (1976); Polar Ice Cream \& Creamery Co. v. Andrews, 375 U.S. 361, 374-75 (1964). Indeed, in a case involving shrimp fishing off the southeastern states, the Court reported an actual, flagrant instance of fragmentation and retaliation: "Restrictions on non-resident fishing in the marginal sea, and even prohibitions against it, have now invited retaliation to the point that the fishery is effectively partitioned at the state lines ... ." Toomer v. Witsell, 334 U.S. 385, 388 (1948).

27. 303 U.S. 177 (1938).

28. The other passages are United States v. Carolene Prods. Co., 304 U.S. 144, 152 n.4 (1938), and Helvering v. Gerhart, 304 U.S. 405, 412 (1938).

29. Barnwell Bros., 303 U.S. at 185 n.2.

30. Id. at 187.

31. E.g., Edwards v. California, 314 U.S. 160, 174 (1941).

32. J. Choper, Judicial Review and the National Political Process 205-06 (1980); J. Ely, Democracy ANd Distrust: A Theory of Judicial Review 83-84 (1980); L. Tribe, supra note 4, at 326-27; Tushnet, Rethinking the Dormant Commerce Clause, 1979 WIS. L. REV. $125,132-41$. 
fication again. ${ }^{33}$

\section{B. Contrary Considerations}

\section{State Independence}

There are at least two considerations that may limit the doctrine disfavoring discriminations. One is our tradition of state independence. Over the years, extending back to the adoption of the Constitution, we have accepted that certain regulations are within the independent domain of the states and thus not subject to national invalidation. Less than a decade ago the Supreme Court temporarily reasserted this principle in relation to the power of Congress. ${ }^{34}$ More recently, it has invoked the same principle in several cases dealing with judicial power to invalidate state discriminations against interstate commerce. For example, in Reeves, Inc. v. Stake, ${ }^{35}$ South Dakota had adopted a policy favoring local buyers of cement produced by a state-owned factory at a time of cement shortage. In upholding the policy, the Court claimed that its decision was supported "by considerations of state sovereignty, the role of each State 'as guardian and trustee for its people' ...."36 Likewise, in a more recent case the Court asserted that "the legal expectation that under certain circumstances each State may restrict water within its borders has been fostered over the years ....",37

Perhaps the inost enduring of these traditions is the power of the states to proinote the health and safety of their inhabitants. In the very first Supreme Court decisions concerning state interference with interstate commerce, Chief Justice Marshall especially acknowledged the state interest in matters of health. ${ }^{38}$ Decisions during the current era have continued to treat the protection of health and safety as the heart of the states' responsibilities. Typical of these is Huron Portland Cement Co. $v$ City of Detroit, ${ }^{39}$ in which the Court asserted, "Legislation designed to free from pollution the very air that people breathe clearly falls within the exercise of even the most traditional concept of . . the police power." 40

33. E.g., Minnesota v. Clover Leaf Creamery Co., 449 U.S. 456, 473 n.17 (1981); Raymond Motor Transp., Inc. v. Rice, 434 U.S. 429,447 (1978).

34. National League of Cities v. Usery, 426 U.S. 833 (1976) (holding the federal Fair Labor Standards Act unconstitutional as applied to states as employers in "areas of traditional governmental functions"). But see Garcia v. San Antonio Metro. Transit Auth., $105 \mathrm{~S}$. Ct. 1005 (1985) (overruling Nat'l League of Cities).

35. 447 U.S. 429 (1980).

36. Id. at 438 (footnote omitted) (quoting Atkins v. Kansas, 191 U.S. 207, $222-23$ (1903)).

37. Sporhase v. Nebraska ex rel. Douglas, 458 U.S. 941, 956 (1982).

38. Willson v. Black Bird Creek Marsh Co., 27 U.S. (2 Pet.) 245, 250 (1829); Gibbons v. Ogden, 22 U.S. (9 Wheat.) 1, 205 (1824).

39. 362 U.S. 440 (1960).

40. Id. at 442; see also passages cited infra note 183 . 


\section{Limits of Judicial Competence}

Another contrary consideration relates to the competence of courts. Even if a rule may be sound constitutional interpretation, it may be too difficult or too delicate for judicial enforcement; it may be appropriate for enforcement only by political or moral means. The Supreme Court invoked this consideration too in Reeves, Inc. v. Stake, asserting that "the competing considerations in cases involving state proprietary action often will be subtle, complex, politically cliarged, and difficult to assess under traditional Commerce Clause analysis. . . . [T]he adjustment of interests in this context is better suited for Congress than this Court." ${ }^{41}$

Of the types of doctrine that may test the limits of judicial competence, two warrant special mention here. One would require the courts to distinguish among regulations according to the subjective intentions of those who enacted them. For example, the courts might undertake to determine whether the lawmakers meant to achieve economic or noneconomic ends. As we will see in greater detail later, judicial inquiries into the intentions behind regulations attacked as unconstitutional have proved especially difficult and delicate. ${ }^{42}$ The alternative of distinguishing according to the so-called "prinary" effects of the regulations has not proved manageable either. ${ }^{43}$

Another type of doctrine testing the himits of judicial competence would require the courts to assess the full economic incidence of state regulations. For example, the courts might undertake to determine whether the overall economic benefits and burdens of a regulation favor local inhabitants against outsiders. Even expert economists might find themselves hard put to make this deternnination. ${ }^{44}$

\section{Indeterminacy of the Considerations}

In the description of doctrine that follows, we repeatedly encounter unsettled issues. For example, we first consider whether state regulations that shift noneconomic burdens to people in other states should be treated as if they were discriminatory. According to conventional legal methods, these issues might be most cogently resolved in light of the reasons that the Supreme Court disfavors discriminatory regulations. If the reasons do not apply, the regulations should not be treated as if they were disfavored discriminations.

Unfortunately, the conventional legal methods do not work well here. On a particular issue, such as the status of regulations that shift

41. 447 U.S. 439 (1980).

42. See infra text accompanying notes $223-33$.

43. L. TRIBE, supra note 4, at 340.

44. See infra text accompanying notes 140-41. 
noneconomic burdens to the people of other states, the reasons for disfavoring state discriminations may point in opposite directions. Adherence to the intent of the Framers may suggest that these regulations are permissible, but concern for biased political processes may support their invalidity. Moreover, even if all of the main reasons for disfavoring state discriminations dictate invalidation of the regulations, the reasons pressing in the opposite direction may overcome them. Thus, notwithstanding all other considerations, regulations that shift noneconomic burdens may be justified by our traditions of state independence in matters of health and safety.

Most inconvenient of all is the fact that none of these considerations, even when invoked individually, may point in a determinate direction. Professor Dworkin has undertaken an adroit campaign against appeals to the intent of the Framers, and legislative intent generally, ${ }^{45}$ while Dean Ely has made it much harder than it used to be to rely confidently on tradition as a criterion of constitutional interpretation. ${ }^{46}$ The other considerations just recited may be no more helpful in determining sound doctrime. Surmises about what kinds of state regulations provoke interstate reprisals or are the product of biased political processes are apt to be based on shallow political science. Even assertions that certain inquiries exceed the limits of judicial competence may reflect an unreflective legalism.

\section{II}

\section{DEFINITION OF DISCRIMINATION}

In two leading cases on the subject of state interference with interstate commerce, renowned Justices of the Supreme Court used phrases that contribute to a tentative definition of discrimination. In Baldwin v. G.A.F. Seelig, Inc., Justice Cardozo asserted that the regulation before the Court would "suppress or mitigate the consequences of competition between the states," 47 that it would establish "an economic barrier against competition with . . . another state or . . its residents." 48 This characterization emphasized the deleterious effects of the regulation on economic competition.

Shortly thereafter, in South Carolina Highway Department v. Barnwell Bros. ${ }^{49}$ Justice Stone propounded a more general and abstract dictum. He wrote that the commerce clause forbids state regulations that "gain for those within the state an advantage at the expense of those

45. E.g., Divorkin, The Forum of Principle, 56 N.Y.U. L. REv. 469, 471-500 (1981).

46. J. ELY, supra note 32, at 60-69.

47. 294 U.S. at 522.

48. Id. at 527 .

49. 303 U.S. 177 (1938). 
without," 50 that are "a means of gaining a local benefit by throwing the attendant burdens on those without the state." potentially went well beyond cases of economic competition between states.

Subject to reconsideration in Section $C$ of this Part, I will employ a definition of discrimination that combines the phrasing of Justices Cardozo and Stone: A regulation is discriminatory if it imposes greater economic burdens on those outside the state, to the economic advantage of those within. This definition concentrates on economic consequences but does not require that they be felt by people usually thought of as competitors.

The proposed definition of discrimination gives rise to two main issues: what kinds of economic burdens are sufficient to constitute a disfavored discrimination, and what is a sufficiently unequal distribution of burdens and advantages. On the two issues, as on all others that concern whether the regulation is discriminatory, the party challenging the regulation, not the state, has the burden of proof. ${ }^{52}$ As a recent case illustrates, the court will resolve against the challenger a substantial uncertainty in the record about whether the regulation is discriminatory. ${ }^{53}$

\section{A. Economic Burdens}

\section{Sufficient Burdens}

Practically any type of economic burden may make a regulation discriminatory. The prototypical discrimination against incoining commerce forbids the importation or sale of goods or services produced outside the state in coinpetition with local goods or services. ${ }^{54}$ Yet burdens less drastic than outright prohibition of inportation or sale will suffice. For example, the Supreme Court has invalidated state regulations that forbid the sale of out-of-state goods below a certain price, that inpose additional costs on their sale, or that forbid effective ways of advertising them. ${ }^{55}$

Likewise, a prototypical discrimination against outgoing commerce forbids the exportation of desirable goods or services produced within the

50. Id. at 184 n.2.

51. Id. at 186 .

52. Hughes v. Oklahoma, 441 U.S. 322,336 (1979).

53. Sporhase v. Nebraska ex rel. Douglas, 458 U.S. $941,955-56$ (1982).

54. E.g., Great Atl. \& Pac. Tea Co. v. Cottrell, 424 U.S. 366 (1976); Polar Ice Cream \& Creamery Co. v. Andrews, 375 U.S. 361 (1964); Dean Milk Co. v. City of Madison, 340 U.S. 349 (1951).

55. Huut v. Washington Apple Advertising Comm'n, 432 U.S 333 (1977); Baldwin v. G.A.F. Seelig, Inc., 294 U.S. 511 (1935). 
state for consumption by outsiders. ${ }^{56}$ Yet the Supreme Court has also invalidated less drastic restrictions on exports-for example, regulations that make it very difficult to obtain goods for sale outside the state or that forbid exportation not for consumption but for processing elsewhere. ${ }^{57}$

\section{Insufficient Burdens}

From time to time, the Supreme Court has suggested that certain types of economic burdens are insufficient to warrant disfavoring a discriminatory regulation. In one group of cases, the Court distinguished between regulations that obstruct the shipment of goods to out-of-state buyers and those that make out-of-state buyers pay more for the goods. In H.P. Hood \& Sons v. Du Mond, ${ }^{58}$ New York forbade a distributor to set up a new plant to receive milk for sale outside the state. In the course of invalidating the order, the Court sought to distinguish a prior case, Milk Control Board. v. Eisenberg Farm Products, ${ }^{59}$ in which it had allowed Peimsylvania to prescribe the minimum price at which distributors imiglit buy milk for resale outside as well as inside the state. The majority explaimed that Eisenberg had not involved a ban on the shipment of milk to other states. ${ }^{60}$ The Eisenberg opinion itself foreshadowed this reasoning, ${ }^{61}$ and in two cases decided within a couple of years after Hood, the Court confirmed the distinction between "prohibition" of interstate commerce and lesser regulations such as price fixing. ${ }^{62}$

The key case in this line, Eisenberg, can be explained on grounds inucli more obvious than that it involved an insufficient economic burden. The Peimsylvania regulation did not distribute its burden more heavily on inilk distributors and consumers outside the state than on those within. Indeed, Pennsylvania producers exported only about ten percent of the milk subject to the ninimum price regulation to other states. ${ }^{63}$

In another group of cases, the Suprenie Court has distinguished between state regulations that discriminate against out-of-state goods and those that discriminate against out-of-state retailers of goods. The first two of these cases made the point only by implication. In Panhandle

56. E.g., New England Power Co. v. New Hampshire, 455 U.S. 331 (1982); Hughes v. Oklahoma, 441 U.S. 322 (1979).

57. Pike v. Bruce Church, Inc., 397 U.S. 137 (1970); H.P. Hood \& Sons v. Du Mond, 336 U.S. 525 (1949); Toomer v. Witsell, 334 U.S. 385 (1948).

58. 336 U.S. 525 (1949).

59. 306 U.S. 346 (1939).

60. Hood, 336 U.S. at 531 ; $i d$. at 571 (dissenting opinion).

61. Eisenberg, 306 U.S. at 352.

62. Panhandle E. Pipe Line Co. v. Michigan Pub. Serv. Comm'n, 341 U.S. 329, 336 (1951); Cities Serv. Gas Co. v. Peerless Oil \& Gas Co., 340 U.S. 179, 188 (1950).

63. Eisenberg, 306 U.S. at $350,353$. 
Eastern Pipe Line Co. v. Michigan Public Service Commission, ${ }^{64}$ the state in effect had required a company outside the state to sell natural gas to industrial custoiners within the state through a local distributor rather than directly. The acknowledged state interest was to provide incoine for the local distributor as well as to hold down the prices paid by other local customers. ${ }^{65}$ Similarly, in Breard v. City of Alexandria, ${ }^{66}$ the locality had forbidden inost door-to-door selling. Responding to a challenge by a inagazine distributor located outside the state, the Supreme Court recognized that "[the] local retail inerchant . . . has not been unmindful of the effective coinpetition furnished by house-to-louse selling in inany lines."67 Despite these local interests, in both cases the Supreme Court expressly denied that the regulations were discriminatory and upheld thein. It relied in part on the fact that the regulations did not forbid interstate cominerce itself. The pipeline company could still import natural gas into Michigan for resale, and the magazine distributor had other inethods of retailing available. ${ }^{68}$

A recent Supreme Court decision drew the distinction much more explicitly. In Exxon Corp. v. Governor of Maryland, ${ }^{69}$ the state had forbidden petroleuin producers and processors to operate retail service stations. The record established that ninety-eight percent of the stations burdened by the regulation were operated from outside the state and that ninety-nine percent of those not burdened were operated by local inhabitants. Yet again the Supreme Court upheld the regulation, denying that it was discriminatory. The Court advanced as its main reason that not all retailers outside the state were burdened by the regulation, an argument that will later be shown to be aberrant. ${ }^{70}$ Just before leaving tle claim of discrimination, however, the Court added a footnote making the further argunent that since Maryland neither produced nor processed petroleum, the regulation did not affect competition by out-of-state goods but only out-of-state retailers of goods. ${ }^{71}$ Later in the opinion, the Court suggested that coinpetition among retailers is altogether outside the contmerce clause. ${ }^{72}$

The inain argument that may be made in behalf of the distinction drawn by this line of cases is that their doctrine has endured in Supreine Court practice for roughly a generation. Yet even this argunent is ques-

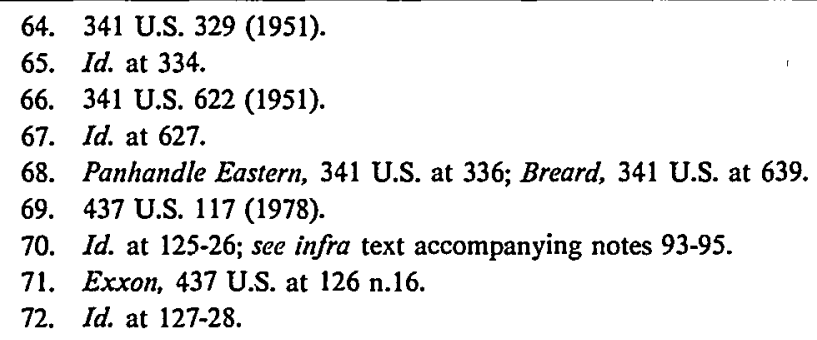


tionable. Two dissenters in Breard relied heavily on the Court's holdings in the so-called "drummer cases," the most recent of which had been decided only five years before. ${ }^{73}$ According to these cases, license fees inposed on people who solicit orders for goods to be delivered at a future time discriminate in effect against sellers from outside the state and violate the commerce clause. These holdings implicitly reject the proposition that regulation of retailing is outside the scope of the clause. ${ }^{74}$

Another aspect of commerce clause doctrine may be even more devastating to the retailing line of cases. It is settled beyond dispute that state regulation of transportation is within the coinmerce clause; perhaps the three most influential cases on state interference with interstate commerce, Gibbons v. Ogden, ${ }^{75}$ Cooley v. Board of Wardens, ${ }^{76}$ and Southern Pacific Co. v. Arizona, ${ }^{77}$ all concerned transportation. Yet regulation of interstate transportation does not, in itself, interfere witl out-of-state goods. It merely has the potential of burdening their inportation, just as discrimination against out-of-state retailers of goods does.

The Supreme Court may have tacitly abandoned the doctrine of the retailing cases in Lewis v. BT Investment Managers, Inc. ${ }^{78}$ Florida had forbidden ownership of local investment businesses by certain financial institutions whose principal operations were outside the state. It sought to justify the regulation in part as serving an interest in local ownership and control of local financial institutions. Not only did the Court characterize the regulation as discriminatory on its face and ultimately invalidate it; the Court strongly suggested that the state's interest in local ownership was illegitimate. ${ }^{79}$ Arguably the case ineans that discrimination against out-of-state retailers, even when it does not affect the inportation of goods or services, is subject to the commerce clause after all.

The Supreme Court could abandon the doctrine of the retailing cases without necessarily abandoning all of the holdings as well. For

73. Breard, 341 U.S. at 646 (dissenting opinion) (citing Nippert v. City of Richmond, 327 U.S. 416 (1946)).

74. In the first of the drummer cases, the Court relied in part on the fact that the fees also burdened producers of goods outside the state; in the late 19th century, producers aiming at an interstate market often sold their goods through drummers. L. TRIBE, supra note 4, at 356 . In the most recent decision before Breard, however, the Court made no mention of this consideration, perhaps reflecting the changes in commercial practice by the middle of the 20th century. Nippert $v$. City of Richmond, 327 U.S. 416 (1946). Even if the drummer cases turn on the burden that the fees impose on out-of-state goods, the retailing cases may involve a similar burden. For example, in Exxon the Court conceded the possibility "that the consuming public will be injured by the loss of the high-volume, low-priced stations," an injury that might well result in lower consumption of petroleum from other states. Exxon, 437 U.S. at 128.

75. 22 U.S. (9 Wheat.) 1 (1824).

76. 53 U.S. (12 How.) 299 (1851).

77. 325 U.S. 761 (1945).

78. 447 U.S. 27 (1980).

79. Id. at $43-44$. 
example, in Panhandle Eastern the Court stressed that Congress had authorized extensive state independence in regulating sales of natural gas to consumers. ${ }^{80}$ Professor Tushnet suggests that Breard might be explained on the ground that sufficient burdens fell on door-to-door sellers froin within the state to render the burden nondiscriminatory. ${ }^{81}$ Perhaps Exxon was one of those rare cases in which, because of the gasoline crisis of the middle 1970's, the state had an adequate justification for its discrimination in effect. ${ }^{82}$

\section{B. Inequality of Burdens and Advantages}

\section{Extent of Inequality}

It would be difficult to conceive of a state regulation that allocated all of its burdens to those outside the state or all of its advantages to those within. Yet in two recent cases involving protection of the environinent, the Supreine Court talked as if it had found such a regulation. In City of Philadelphia v. New Jersey, ${ }^{83}$ the state prohibited the importation for disposal of nost garbage generated outside the state. In Hughes $v$. Oklahoma ${ }^{84}$ the state forbade the exportation of natural minnows for sale outside the state. In these cases the Court claimed that outsiders carried the "full" or "entire" burden of the regulation. ${ }^{85}$ Understood hiterally, this claim was not true. In the New Jersey case one set of plaintiffs challenging the regulation was local landfill owners whose supply of waste had been reduced, and in the Oklahoina case, as the dissent pointed out, local exporters of minnows were burdened equally with importers outside the state. ${ }^{86}$

Presumably the Supreme Court ineant that within an miportant category of people affected by the regulations, those outside the state bore the full burden. In the New Jersey case the category was people needing to dispose of garbage; in the Oklahoina case it was ininnow consuiners. Thus, for a distribution of burdens to count as discriminatory, it is not necessary to take every group affected by the regulation into account. It is apparently sufficient that the burdens are distributed unequally within an inportant category of those affected. ${ }^{87}$

Even within that category, the extent to which burdens or advan-

80. 341 U.S. at 334.

81. Tushnet, supra note 32, at 138.

82. It is also possible to account for Exxon on the ground that the Court did not suspect the discrimination in effect of being purposeful. See infra text accompanying notes 206-19.

83. 437 U.S. 617 (1978).

84. 441 U.S. 322 (1979).

85. Hughes, 441 U.S. at 337; Philadelphia, 437 U.S. at 628.

86. Hughes, 441 U.S. at 344 (dissenting opinion); Philadelphia, 437 U.S. at 619.

87. I discuss whether it is necessary for the inequality to be between people in the same economic category at infra text accompanying notes 132-43. 
tages are distributed unevenly is necessarily a matter of degree. The Supreme Court recognized this in the leading case of Dean Milk Co. $v$. City of Madison, ${ }^{88}$ in which the city forbade the sale of milk not pasteurized within five miles of the city center. The Court recited the fact that "Wisconsin milk from outside the Madison area is subjected to the same proscription as that moving in interstate commerce," but without further explanation it labelled that fact "immaterial."89 Presumably the Court had in mind the additional fact that the Wisconsin pasteurizers inside the Madison area were not subject to the regulation, whereas all pasteurizers in other states were burdened by it. In other words, every processor given a relative advantage by the regulation was within the state. Perhaps the Court also recognized the danger that eventually the state might be completely carved up into regional pasteurizing districts, so that every pasteurizer within the state would enjoy a local haven in which it could operate free of competition from those outside the state. In a later case, Florida appeared to have instituted such a state-wide regional scheme. ${ }^{90}$

In Dean Milk, not all of those burdened by the regulation were outside the state, but all of those advantaged were inside the state. In Hunt v. Washington Apple Advertising Commission, ${ }^{91}$ the pattern was the reverse. The North Carolina regulation forbade the labeling of apples according to nonfederal grading systems, putting those who did so at a competitive disadvantage. As Justice Blackmun stressed in a later case, soine apple producers in other states benefited from the regulation because they did not use grading systeins of their own. ${ }^{92}$ At the same time, since it appeared that no local producers used their own grading systems, the disadvantages of the regulation fell entirely on outsiders. That is, not all of those advantaged were inside the state, but all of those burdened by the regulation were outside the state. This pattern, too, was sufficient to constitute a discrimination. In a case decided last term, the Supreme Court tacitly reaffirmed the proposition. ${ }^{93}$

To this line of cases there is one anomalous exception. Just a year after Hunt, the Supreme Court impliedly took back what it held there. As described before, the state law at issue in Exxon Corp. v. Governor of Maryland ${ }^{94}$ forbade petroleum producers and processors to operate retail service stations. The record established that ninety-eight percent of

\footnotetext{
88. 340 U.S. 349 (1951).

89. Id. at 354 n.4.

90. Polar Ice Cream \& Creamery Co. v. Andrews, 375 U.S. 361, 364 n.1 (1964).

91. 432 U.S. 333 (1977)

92. Exxon Corp. v. Governor of Maryland, 437 U.S. 117, $146-47$ (1978) (concurring and dissenting opinion) (referring to Hunt v. Washington Apple Advertising Comm'n, 432 U.S. 333, 349
} (1977)).

93. Northeast Bancorp, Inc. v. Board of Governors, 105 S. Ct. 2545, 2553.54 (1985).

94. 437 U.S. 117 (1978). 
the stations burdened by the regulation were operated from outside the state and that ninety-nine percent of those not burdened were operated by local inhabitants. Yet the Court denied that the regulation was discriminatory, mainly because not all retailers outside the state were burdened by the regulation. Notwithstanding the protests of the dissenter, the majority never took the trouble to reconcile Hunt on this point. ${ }^{95}$

It is not possible to specify how uneven the distribution of burdens and advantages must be to count as a discrimination. For an example of a problematic case, consider Minnesota v. Clover Leaf Creamery Co., ${ }^{96}$ in which the state barred the retail sale of milk in rigid plastic nonreturnable containers. On the one hand, since plastic resin was inade entirely in other states, the only producers of raw inaterials for milk containers burdened by the regulation were outsiders. Moreover, the regulation gave a relative advantage to producers of pulpwood for cardboard containers, many of whom were within the state. On the other hand, there were also pulpwood producers outside the state. Moreover, the regulation did not burden producers of plastic resin for either flexible or returnable plastic containers, all of whom, as just noted, were outside the state. ${ }^{97}$ Thus, within the category of people producing raw materials for inilk containers, all of those burdened were outside the state, but the extent of the burden was relatively small, and to soine extent people outside the state were also advantaged by the regulation. Perhaps this is what the Supreine Court had in mind when, in upholding the Minnesota law, it suggested that a regulation is not discrinmatory "simply because it causes some business to shift from a predominantly out-of-state industry to a predominantly in-state industry." 98 The Court also intimated that the category of people producing raw materials may not have been sufficiently iinportant to render the regulation discriminatory, especially as compared to other groups such as milk distributors and retailers as to whom no discrimination was claimed. ${ }^{99}$

\section{Other Issues}

At least one other issue has emerged in recent Supreine Court cases that is worth inentioning. Thus far we have spoken of those outside and inside the state as if it were always evident on which side of the line a party falls. Yet a person's location can be determined, among other criteria, by doinicile, residence, or mere physical presence, and the tests are even inore multifarious in the case of business associations. Thus, in

\footnotetext{
95. Id. at 145-46 (concurring and dissenting opinion); id. at 125-26.

96. 449 U.S. 456 (1981).

97. Id. at $472-73$ (1981).

98. Id. at 474 (emphasis added).

99. Id. at 473 .
} 
Lewis v. BT Investment Managers, Inc., ${ }^{100}$ the Florida investment case, the question arose whether place of principal operations, the criterion in the regulation, separated businesses outside and inside the state. Without much discussion, the Court ruled that it did. ${ }^{101}$ This suggests that a wide variety of criteria for determining location nuay be deened to discriminate against outsiders.

\section{Unsettled Issues}

Thus far, we have worked with the definition of discrimination proposed at the outset: a regulation is discrininatory if it puts greater economic burdens on people outside the state, to the economic advantage of those within. It is time now to consider whether this definition is too narrow or too broad. On the one hand, some Supreme Court decisions suggest that the shifting of noneconomic burdens to people elsewhere niay also constitute discrimination, and so may the allocation of undue econormic benefits to local inhabitants. On the other hand, other decisions suggest that an inequahity is not discriminatory unless it is between econonic counterparts imside and outside the state. Finally, the Court niay greatly disfavor certain state regulations that unduly isolate the state froin the conipetitive national econony even though they are not discriminatory at all.

\section{Noneconomic Burdens}

Increasingly, states seein to be adopting regulations that shift noneconomic burdens, such as health and safety hazards, to the people of other states. Two recent cases raise the question whether this inay constitute discrimination, even when the econonic burdens of the regulations are nondiscriminatory.

In Kassel v. Consolidated Freightways Corp., ${ }^{102}$ Iowa had barred trucks sixty-five feet long froin its highways. It did so, let us assume, not because these trucks are especially hazardous, but because all long trucks create hazards, and to ban these trucks reduced highway hazards proportionately. The effect of the regulation was to deffect the trucks to the highways of neighboring states, thereby putting greater safety burdens on road-users in those states. Arguably on this ground alone, two Justices treated the regulation as improper, and four others suggested that they might also have done so if the regulation had been attacked directly on this ground. ${ }^{103}$ On this view, a regulation that puts greater noneconounic

100. 447 U.S. 27 (1980).

101. Id. at 42; see also Northeast Bancorp, Inc. v. Board of Governors, 105 S. Ct. 2545, 2548-49, 2553-54 (1985) (treating "principal place of business" as a discriminatory criterion).

102. 450 U.S. 662 (1981).

103. Id. at $685-86$ (concurring opinion); id. at $677-78$ (plurality opinion). 
burdens on people elsewhere, to the advantage of local inhabitants, may be a disfavored discrimination.

In City of Philadelphia v. New Jersey, ${ }^{104}$ however, the Court implicitly approved a hypothetical state regulation that would result in disproportionate noneconomic burdens. In that case, the state liad forbidden the importation for disposal of most garbage generated outside the state. It sought to justify the regulation mainly on the ground that garbage caused pollution and loss of scarce open space. While recognizing these concerns as legitimate, the Supreme Court held that the means of deahing with them constituted economic discrimination. On the way to this conclusion, however, the Court assumed for the sake of the argument "that New Jersey inay pursue those ends by slowing the flow of all waste into the State's remaiming landfills, even though interstate commerce may incidentally be affected." ${ }^{105}$ Yet such a regulation would put greater burdens of environmental damage on people outside the state to the advantage of those within. Indeed, the regulation might eventually oblige people within the state, as well as outsiders, to dispose of more of their garbage elsewhere.

There is at least one possible alternative to these two clear-cut positions. The Supreme Court might hold that shifting the noneconomic burdens of an activity to people elsewhere is discriminatory if, but only if, the state continues to enjoy the economic beneffts of the activity. On this view, the Iowa regulation would be discriminatory if local shippers continued to use long trucks on all but the local segnients of their shipments. It might not be discriminatory if the state also forbade local shippers to use long trucks for any part of their shipments, inside or outside the state. ${ }^{106}$

This alternative is at odds with another part of the prior analysis. As noted previously, it is not necessary that every group inside the state be advantaged relative to those outside for a regulation to be discriminatory. ${ }^{107}$ If the burdens are distributed unequally within at least one important category of those affected, it is immaterial that local people in a different category are burdened by the regulation. On this view, the Iowa regulation would be discriminatory if it increased highway accidents outside the state to the advantage of local highway users. The state could not save the regulation by putting an additional burden on local

104. 437 U.S. 617 (1978).

105. Id. at 626 (emphasis in original). The Court undercut this assumption somewhat later in the opinion by condemning "the attempt by one State to isolate itself from a problem common to many by erecting a barrier against the movement of interstate trade." Id. at 628 .

106. Of course, such a prohibition might then be especially vulnerable on general commerceclause grounds. It might also be challenged as a form of "isolationism," a concept discussed below. See infra text accompanying notes 144-56.

107. See supra text accompanying notes 83-99. 
shippers any more than the burden on local landfill owners saved the New Jersey garbage regulation.

Looking to the Supreme Court's reasons for disfavoring discriminatory regulations and to related considerations, the proper resolution of this issue is still doubtful. According to the Supreme Court, the state actions that concerned the Framers all involved the imposition of economic burdens-shipping taxes, fees, and other expenses. The Framers may not have had in mind the shifting of noneconomic burdens. Moreover, as noted before, the Court associates our tradition of state independence mainly with noneconomic interests such as health and safety, rather than with economic regulation. ${ }^{108}$ Perhaps this tradition would permit a state to shift noneconomic harms to other states, so long as those states are also free to protect themselves.

Other considerations are opposed to a distinction between economic and noneconomic burdens. Application of such a distinction might impose on the Supreme Court the perennially troublesome task of detecting the primiary purpose or effect of a regulation. For example, in the Iowa truck case, the regulation ostensibly shifted both the safety hazard and the financial burden of long trucks. To deflect them from Iowa's highways would save its people the cost of road repairs, police personnel, and higher insurance rates. ${ }^{109}$

\section{State Economic Benefits}

Discrimination might consist not only of imposing unequal burdens on people outside the state but also of granting undue benefits, such as state money or resources, to local people. In a line of cases beginning in 1976, however, the Supreme Court has held not only that the stringent rules relating to discriminatory regulations do not apply to the granting of certain benefits but that these benefits are outside the commerce clause altogether. In doing so, the Court has not defined the doctrine in terms of a difference between granting benefits and imposing burdens. Rather, it has distinguished state regulation of the private economic market, which is subject to the commerce clause, from state participation in the inarket, which is not. ${ }^{110}$ Several commentators have suggested, however, that what the Court may truly have in mind is the special character of state programs for distributing its own money or resources. ${ }^{111}$

The Supreme Court first applied this distinction in Hughes v. Alex-

108. See supra text accompanying notes $38-40$.

109. Kassel, 450 U.S. at 667.

110. E.g., Reeves, Inc. v. Stake, 447 U.S. 429, 436-37 (1980); Hughes v. Alexandria Scrap Corp., 426 U.S. 794, 808-09 (1976).

111. Anson \& Schenkkan, Federalism, the Dormant Commerce Clause, and State-Owned Resources, 59 TEx. L. REv. 71, 89-90 (1980); Hellerstein, Hughes v. Oklahoma: The Court, the Commerce Clause, and State Control of Natural Resources, 1979 SUP. CT. REV. 51, 74, 77. 
andria Scrap Corp., ${ }^{112}$ involving a Maryland statute that favored local processors of derelict automobiles as recipients of a state subsidy instituted to encourage disposal of the automobiles. ${ }^{13}$ Four years later, in Reeves, Inc. v. Stake, ${ }^{114}$ it extended the holding to a policy of Soutli Dakota that preferred local buyers of cement produced by a state-owned factory at a time of cernent shortage. ${ }^{115}$ In the course of its opinion, it also placed outside the commerce clause state preferences for local producers in the purchase of goods and services, such as printing, for state use. ${ }^{116}$ More recently the Court took the same position in White v. Massachusetts Council of Construction Employers, ${ }^{117}$ concerning a Boston regulation favoring the einployment of local workers in construction projects funded by the city. ${ }^{118}$

It is unclear how much further the Supreine Court may extend this line of cases, for it has not yet taken any occasion to call a halt. The closest it has come was in a case last tern, South-Central Timber Development, Inc. v. Wunnicke. ${ }^{119}$ In connection with the sale of timber on state-owned land, Alaska forbade the buyer to process the timber outside the state. Four of tlie eight Justices participating in the decision voted to invalidate the requirement as a discrimination against interstate and foreign cominerce. These judges acknowledged that, according to the Court's recent decisions, the state nay sell its timber exclusively to its own residents witliout running afoul of the commerce clause. Having sold the timber, however, the state may not, in their view, require the buyers to deal ouly with local residents. ${ }^{120}$ Stated inore generally, the distinction is between state programs that give local people an advantage over outsiders in their dealings, on the one hand, with the state itself, and on the otlier hand, witl otlier private parties. The latter constitutes a disfavored discrimination, even when it is associated with the granting of benefits rather than the imposition of burdens.

Assuming the validity of the distinction, there are at least two ways in which it inight be elaborated. A far-reaching rule would count as discriminatory any program in which the effect of the benefits is to advantage local people in their dealings with private parties. Certain nembers

112. 426 U.S. 794 (1976).

113. Id. at 796-801.

114. 447 U.S. 429 (1980).

115. Id. at $430-33$.

116. Id. at 437 n.9.

117. 460 U.S. 204 (1983).

118. Id. at 205-06. In United Bldg. \& Constr. Trades Council v. Mayor of Camden, 465 U.S. 208 (1984), however, the Court held that discrimination against nonresidents in hiring for city construction projects is subject to challenge under the privileges and immunities clause of article four.

119. 104 S. Ct. 2237 (1984).

120. Id. at $2244-47$ (plurality opinion). 
of the Supreme Court may favor this position. Justices Brennan and White have almost invariably voted to invalidate the unequal distribution of state benefits. Moreover, dissenting in the Maryland automobile case, they argued in part that the subsidy should be disfavored because its effect was to enable local processors to outbid competitors in other states in their dealings with suppliers of derehict Maryland automobiles. ${ }^{121}$ For the time being, however, a majority of the Court seems to have rejected this position.

A more limited rule would characterize as a disfavored discrimination only those programs in which the very terms of the benefit favor local people in their dealings with private parties. A majority of the Supreme Court may be inclined toward this position. In the Boston hiring case, seven Justices subscribed to the view that "there are some limits on a state or local government's ability to impose restrictions that reach beyond the immediate parties with which the government transacts business." 122 They found these linits not exceeded in the Boston case only because "[e]veryone affected by the order is, in a substantial if informal sense, 'working for the city." "123 In other words, the program disadvantaged people outside the state only in their dealings with the city itself. ${ }^{124}$

Of course there is a third alternative, that in the granting of state benefits the state may attach wliatever conditions it pleases in favor of local residents. Certain Justices may inclime toward this position. Justices Burger and Rehnquist, for example, have almost invariably voted to uphold the unequal distribution of state benefits. Moreover, dissenting from an equivocal outcome in the Alaska timber case, Justice Rehnquist came close to suggesting that in every case, local residents given an advantage in their dealings with private parties should be deemed to be deahing with the state itself. ${ }^{125}$ This position has yet to be clearly rejected by a majority of the Supreme Court.

In liglit of the considerations governing the doctrine of state discriminations, there is solnething to be said in favor of the proposed distinction between state benefits that give local residents an advantage over outsiders in their dealings, on the one hand, with the state itself, and on the otlier hand, witli private parties. As the Supreme Court suggested in the South Dakota cement case, our tradition of state autonomy may entitle a state to favor its own people in direct dealings with the state. ${ }^{126}$ To

121. Hughes, 426 U.S. at $824-25 \mathrm{n} .6$ (dissenting opinion).

122. White, 460 U.S. at 211 n.7.

123. Id.

124. All of the members of the Court also joined in drawing this distinction under the privileges and immunities clause of article four, a provision that the Court regards as akin to the commerce clause. Hicklin v. Orbeck, 437 U.S. 518, 528-34 (1978).

125. South-Central, 104 S. Ct. 2248-49 (dissenting opinion).

126. Reeves, Inc. v. Stake, 447 U.S. 429,438 n.10 (1980). 
extend the favoritism to private dealings, however, may go beyond this tradition. ${ }^{127}$

On the other hand, if the distinction is applied in a highly flexible way, as seems to have occurred so far, it may not fit conventional notions of judicial regularity. In the Boston hiring case, the city gave construction contracts only to companies that agreed to hire the requisite percentage of local residents. Strictly speaking, the very terns of the program favored workers withm the state in their dealings with private contractors. Yet a majority of the Supreme Court claimed that the local residents benefited by the condition were really dealing with the city itself. ${ }^{128}$ Similarly, in the Alaska timber case, the state sold timber on the condition that the buyers process it within the state, and to compensate for this requirement it charged a "significantly lower price." 129 Using the same line of argument, the two dissenters claimed that "Alaska is merely paying the buyer of the timber indirectly ... to hire Alaska residents to process the timber."130 Yet the plurality voted that the state had overstepped the limits. Perhaps the fact that two other Justices suspended judgment on the issue pending further proceedings below reveals most clearly the indeterininacy of the Court's present position. ${ }^{131}$

\section{Inequality Between Counterparts}

In considering mequality of burdens and advantages, we saw that for a regulation to be discriminatory it is not necessary that every group inside the state be advantaged relative to those outside. It is sufficient if the burdens are distributed unequally within at least one important category of those affected. The result is less clear when the groups burdened and advantaged are not in the same economic category. Is it sufficient to constitute discrimination, as the definition proposed at the outset might suggest, that taking into account all groups affected by the regulation (or at least the most important groups), the regulation imposes greater economic burdens on people outside the state to the economic advantage of those within? Or must there be an inequality between people inside and outside the state wlio belong to the same category-producers, consumers, or whatever?

There is a strong argument from precedent in favor of this additional requirement. In every case during the current era in which the Supreme Court has either characterized a state regulation as discrimina-

127. Moreover, two commentators have argued that when the state is merely distributing its own money or resources, there is no reason to be concerned about biased political processes. Anson \& Schenkkan, supra note 111 , at $89-90$.

128. White, 460 U.S. at $211 \mathrm{n} .7$.

129. South-Central, $104 \mathrm{~S}$. Ct. at 2239.

130. Id. at 2248 (dissenting opinion).

131. Id. at 2247 (concurring opinion). 
tory or treated one as such, those outside the state subjected to greater burdens belonged to the same category as those inside the state advantaged by the regulation.

What is more, there are numerous other cases in which the Supreme Court might have characterized the regulation as discriminatory or treated it as such, except that the inequality was not between people who belonged to the same economic category. Perhaps the clearest examples both involved the fixing of minimum prices. In Parker v. Brown, ${ }^{132}$ California had instituted a program, in the words of the Court:

to control marketing of the [raisin] crop so as to enhance the price or at least to maintain prices by restraints on competition of producers in the sale of their crop.... And since 95 per cent of the crop is marketed in interstate commerce, the prograin may be taken to have a substantial effect on the commerce .... ${ }^{133}$

Likewise, in Cities Service Gas Co. v. Peerless Oil \& Gas Co., ${ }^{134}$ decided almost a decade later, Oklahoma forbade the sale of certain natural gas at the wellhead below a prescribed price in order to prevent what the Court called "uneconomic dissipation of one of its chief natural resources." 135 Presumably, nearly all of the gas involved was eventually consumed in other states.

At the least, these regulations had unequal effects on the two economic groups most obviously concerned; they put substantial economic burdens on consumers, nearly all of whom were outside the state, to the economic advantage of many local producers. What is more, they did this by curtailing price competition between the producers within the state. Yet in both cases, without addressing the objection just recited, the Supreme Court not only upheld the regulations but expressly denied that they were discriminatory. ${ }^{136}$

It is possible to account for these decisions on a ground other than that the mequality was between people in different economic categories. Elsewhere in Parker, the Supreine Court stressed that the federal governinent had cooperated in the state program, and in H.P. Hood \& Sons $v$. Du Mond the Court distinguished Parker in part on that ground. ${ }^{137}$ Likewise, in Cities Service, the Court alluded briefly to the possibility that there might also be a federal policy of encouraging sale of natural gas at higher prices. ${ }^{138}$ Thus, the Court arguably sustained these two regulations because in its view Congress had consented to them.

132. 317 U.S. 341 (1943).

133. Id. at 359 .

134. 340 U.S. 179 (1950).

135. Id. at 187 .

136. Id. at 188; Parker, 317 U.S. at 368.

137. Hood, 336 U.S. at 537; Parker, 317 U.S. at 364-68.

138. Cities Serv., 340 U.S. at 187. 
The strongest argument against the suggested distinction between inequality among counterparts and noncounterparts rests on the considerations underlying the doctrine of state discriminations. According to the sources cited by the Supreme Court, for example, certain of the state laws about which the Framers were strongly concerned burdened people outside the state who were in a different economic category than the local beneficiaries. For example, what seems to have bothered the Framers most about the state navigation laws was not that they favored local shipowners against their counterparts elsewhere but that they gave the foriner an undue advantage over shippers in states without major ports. As Professor Brown pointed out, it is a short step to a state's use of its near monopoly of a desired resource, such as raisins or natural gas, to extract undue profits mainly from consumers elsewhere. ${ }^{139}$

Against this argument, there stands one important contrary consideration-the limits of judicial coinpetence. When they are dealing with people in the saine economic category, the courts may feel confident that they know an inequality when they see it, without needing to make mice economic judgments. If the inquiry were extended to people in different categories, however, they might have to worry about uncertain economic realities such as who actually bears the incidence of a price increase. Even expert economists might be hard put to determine whether the overall economic benefits and burdens of a regulation favor local inhabitants against outsiders.

In a recent tax case, Commonwealth Edison Co. v. Montana, ${ }^{140}$ the Supreme Court explicitly acknowledged that judicial competence was a decisive consideration in rejecting a claim of discrimination. Montana imposed a high severance tax on coal mined within the state, ninety percent of which was allegedly shipped to other states. Challengers attacked the tax in part as a discrimination agamst interstate commerce, not because coal shipped to other states bore a higher tax rate, but because out-of-state consumers were being burdened for the advantage of local taxpayers and residents generally. Again, the Court was arguably being invited to assess the economic effects of state action on disparate categories of people. The Court declined to do so, in part because of "the "formidable evidentiary difficulties" " in resolving "such issues as elasticity of demand for the product and alternative sources of supply."141

Professor Tushnet has suggested a similar limit upon the Court's competence in an analogous context. Having suggested that distortion of the political process is a reason for disfavoring state discriminations gen-

139. Brown, The Open Economy: Justice Frankfurter and the Position of the Judiciary, 67 YALE L.J. 219, 232 (1957).

140. 453 U.S. 609 (1981).

141. Id. at 619 n.8. 
erally, Professor Tushnet considers whether the distribution of political forces should be examined case-by-case to decide the validity of specific state regulations. ${ }^{142}$ For this purpose, the courts might inquire not just about counterparts inside and outside the state but about the political strength of all groups affected by the regulation. In the end, however, he acknowledges that "examining the political forces other than those in the regulated industries is a task beyond the Court's ability in general." 143

\section{Economic Isolationism}

Finally, two of the leading cases on the subject of state interference with interstate commerce may hold that certain state regulations, even though they do not discriminate against people outside the state, may nevertheless be as greatly disfavored as those that do. What may distinguish these regulations is that, in aid of an anticompetitive local program, they unduly isolate the state from the competitive national economy.

\section{a. Baldwin v. G.A.F. Seelig, Inc.}

In the midst of the Great Depression, New York enacted a statute forbidding the sale of milk within the state unless the milk had been bought from producers above a minimum price. Fearing in part that if the regulation applied only to purchases from local producers, those outside the state might obtain a greater share of the market by charging lower prices, the state extended the regulation to purchases from producers elsewhere. ${ }^{144}$ The Supreme Court treated the regulation as improper in purpose and effect and invalidated it.

Notwithstanding the renown of the author of the opinion, Justice Cardozo, it has aroused substantial criticism. Among other objections, scholars have expressed uncertainty about the very rule of the decision, uncertainty magnified by the frailty of Cardozo's later attempt to reconcile Baldwin with Henneford v. Silas Mason Co. ${ }^{145}$ In the latter case, the Supreme Court upheld a use tax on goods bought in other states equal to the sales tax on goods bought within the state.

Perhaps the narrowest interpretation is Justice White's; he asserted in a later milk case, "Out-of-state milk [in Baldwin] was denied an equal opportunity to compete with New York-produced milk to the extent that the out-of-state supply bore additional transportation charges." ${ }^{146}$ Under this interpretation, the regulation would have been valid if the

142. Tushnet, supra note 32 .

143. Id. at 160 .

144. Baldwin v. G.A.F. Serling, Inc., 294 U.S. 511, 518-20.

145. 300 U.S. 577 (1937); see G. GUNTHER, supra note 4 at 301-02.

146. Polar Ice Cream \& Creamery Co. v. Andrews, 375 U.S. 361, 376 (1964). 
state had allowed producers to absorb the cost of transporting milk to the distributors' plants. Apparently, the agency administering the program forbade this. ${ }^{147}$

If we adopt this interpretation, it is relatively easy to reconcile the decision with the definition of discrimination tentatively adopted at the outset. Assuming that transportation costs of milk retailed within the state were generally greater for milk produced elsewhere, the regulation discriminated in effect by requiring distributors to pay more for such inilk.

Professor Gunther has proposed a broader interpretation of the decision. He distinguishes Silas Mason on the ground that:

Washington's use tax cancelled only the advantage the out-of-state seller had because he was not subject to a sales tax, while New York's scheme in Baldwin cancelled all the advantages the Vermont seller had because of lower costs of production-taxes as well as all other costs. Washington's plan, in short, still permitted some price competition; New York's did not. ${ }^{148}$

Even if this mterpretation is adopted, it is still possible to reconcile the decision with our tentative definition of discrimination. We need only assume that in an unregulated market, producers outside the state might have been apt to sell their milk for less than their counterparts within. In that event, the regulation in effect deprived them of an existing or prospective competitive advantage.

The broadest interpretation of the decision is probably Professor Brown's; he stated the point of the case to be:

Should one state in a federal systen be able to raise its price levels, isolate itself and protect its markets from the outside price competition thereby stimulated? . . . The Court held that the state could not, in its effort to protect its farmers from the outside price competition thereby generated, prohibit the resale of milk inore cheaply purchased. ${ }^{149}$

If this interpretation prevails, the regulation was not discriminatory as we defined the term at the outset. It did not put inherently greater burdens on milk producers outside the state than on those within. The two groups reinained in substantially the same competitive position that they had held before adoption of the ininimum-price program. Its fault lay rather in its purpose and effect of sheltering the state, not merely from local economic competition, but from the competitive national economy.

There are passages in the opinion that may support this view of the case. For example, Justice Cardozo asserted that the Constitution "was

147. Baldwin, 294 U.S. at 520 n.2.

148. G. GUNTHER, supra note 4, at 302.

149. Brown, supra note 139, at 234 (emphasis added). 
framed upon the theory that the peoples of the several states must sink or swim together."150 And again, "What is ultimate is the principle that one state in its dealings with another may not place itself in a position of economic isolation." 151

\section{b. H.P. Hood \& Sons v. Du Mond}

As described before, New York forbade an out-of-state milk distributor to set up a new plant to receive milk for sale outside the state. The state justified its action on the ground that the new plant would subject existing distributors to excessive competition and would deprive their customers of existing milk supplies. ${ }^{152}$ Again the Supreme Court treated the regulation as improper in purpose and effect and invalidated it.

In two dissenting opinions, four Justices criticized the majority at unusual length. They argued in part that there was no evidence in the record of discrimination as it has been tentatively defined-that is, of the state putting greater burdens on milk distributors or consumers outside the state than on those within. In the absence of such evidence, these Justices assumed that the state would equally have protected out-of-state distributors or consumers from new competition from those within the state. ${ }^{153}$

The majority never responded directly to this troublesome objection. One possible answer came from the Court two years later, when it claimed, "The vice in the regulation invalidated by Hood was solely that it denied facilities to a company in interstate commerce on the articulated ground that such facilities would divert milk supplies needed by local consuiners ...." 154 In other words, the Court retrospectively seems to have read the record in Hood as establishing that the state would not have given the same protection to existing consumers in other states. Under this interpretation, the regulation, as administered, was discriminatory according to the proposed definition.

Another, broader answer may come from Justice Jackson himself. In his opinion for the Court in Hood, he quoted extensively from Baldwin, including Justice Cardozo's condemnation of state isolationisin. $\mathrm{He}$ added remarks of his own on the "disability of the state to isolate its own economy " and the "incapacity of the state to protect its own inhabitants froni competition."155 Jackson may have regarded the New York regulation as another instance of a state wrongly isolating itself, not just against

150. Baldwin, 294 U.S. at 523.

151. Id. at 527.

152. H.P. Hood \& Sons v. Du Mond, 336 U.S. 525, 526-29 (1949).

153. Id. at 548-49 (dissenting opinion); id. at 575 (dissenting opinion).

154. Cities Serv. Gas Co. v. Peerless Oil \& Gas Co., 340 U.S. 179, 188 (1950).

155. Hood, 336 U.S. at 538. 
local economic competition, but against national economic forces as well. ${ }^{156}$

\section{c. Observations}

If the Supreme Court strongly disfavors anticompetitive state isolatiomism, the reasons must be different from its reasons for strongly disfavoring state discriminations. Isolatiomist regulations that do not discriminate are not peculiarly likely to mspire retaliation in kind by other states. ${ }^{157}$ They impose significant burdens on counterparts within the state as well as outside. For example, local producers in Baldwin were also prevented from increasing sales by offering to sell their milk at a lower price. For this reason, other states may be reluctant to assume similar burdens $\mathrm{m}$ order to retaliate, and in any event they are unlikely to view these regulations as hostile acts warranting reprisals. For the saine reason, isolatiomist but nondiscriminatory regulations are not likely to be the product of a distorted political process in which the main losers are underrepresented.

\section{III \\ SignifiCANCE OF Discrimination}

It is settled Supreme Court doctrine that if a regulation is discriminatory, the state bears the burden of justifying it. First, the state must prove that it has a legitimate interest to be served by the regulation. ${ }^{158}$ Second, it must show that the regulation serves this interest to a substantial extent. ${ }^{159}$ Third, it must prove that it has no available alternatives to the regulation that are less discriminatory. ${ }^{160}$ Uncertainty in the record on these points, particularly the latter two, is resolved agaimst the state. ${ }^{161}$ The state is excused from its burden of proof only if Congress has consented to the discrimination, which rarely occurs.

It is useful to compare these requirements with the tests currently used by the Supreme Court under the equal protection clause. With regard to the ends of the state regulation, the requirement of a "legitimate" interest is analogous to lax equal protection review; stricter equal

156. As described later, Jackson also argued that state economic interests are inherently illegitimate. See infra text accompanying notes 173-74.

157. On the other hand, emulation is always a possibility. See Schwegman Bros. v. Calvert Corp., 341 U.S. 385, 398 (1951) (dissenting opinion) (fair trade laws with "nonsigner" clauses spread to 42 states within five years).

158. E.g., Hughes v. Oklahoma, 441 U.S. 322, 336 (1979); Dean Milk Co. v. City of Madison, 340 U.S. 349, 354 (1951); see also cases cited infra note 165.

159. Hunt v. Washington Apple Advertising Comm'n, 432 U.S. 333, 353 (1977). See also cases cited infra note 166.

160. E.g., Hughes, 441 U.S. at 336; Hunt, 432 U.S. at 353; Dean Milk, 340 U.S. at 354; see also cases cited infra note 167.

161. Hughes, 441 U.S. at 336, 338 n.20. 
protection scrutiny asks whether the state interest is "important" or even "compelling." "162 With regard to the means that the state has employed, the test of a "substantial" relationship is required both in intermediate equal protection review and under the commerce clause, while the commerce clause's inquiry into available alternatives is akin to the "necessity" test of strict equal protection scrutiny. ${ }^{163}$ In short, under the commerce clause, the Court tests discriminatory regulations by criteria that range from lenient to rigorous.

Not only does doctrine place a considerable burden on the state to justify a discriminatory regulation; the holdings of the Supreme Court suggest that in practice the burden is very heavy. In the fifteen cases durmg the current period in which the Court has characterized the state regulation as discriminatory or treated it as if it were, the Court has rejected the attempt by the states to justify the regulation in every case but one. ${ }^{164}$ It has done so roughly equally on the grounds that the asserted state mterests were illegitimate, ${ }^{165}$ that they were not substantially served by the regulation, ${ }^{166}$ and that alternative less discriminatory ineans were available. ${ }^{167}$

\section{A. State Interests}

\section{Legitimate Interests}

In cases involving both discriminatory and nondiscriminatory state regulations, the Supreme Court has treated a variety of noneconomic interests as legitimate. Most frequently cited are the traditional police power concerns, health and safety. They have manifested themselves in a variety of ways, ranging from highway and employee safety ${ }^{168}$ to health-

162. J. NowAK, R. RotUNDA \& J. YouNG, supra note 4, at 591-94.

163. Id.

164. The exceptional case is Brotherhood of Locomotive Firemen \& Enginemen v. Chicago, R.I. \& Pac. R.R., 393 U.S. 129 (1968).

165. E.g., New England Power Co. v. New Hampshire, 455 U.S. 331, 339 (1982); City of Philadelphia v. New Jersey, 437 U.S. 617, 627-29 (1978); Great Atl. \& Pac. Tea Co. v. Cottrell, 424 U.S. 366, 379-80 (1976); Polar Ice Cream \& Creamery Co. v. Andrews, 375 U.S. 361, 377 (1964); H.P. Hood \& Sons v. Du Mond, 336 U.S. 525, 535 (1949); Edwards v. California, 314 U.S. 160, 173 (1941); Baldwin v. G.A.F. Seelig, Inc., 294 U.S. 511, 522, 527 (1935).

166. E.g., Lewis v. BT Inv. Managers, 447 U.S. 27, 44 (1980); Hughes v. Oklahoma, 441 U.S. 322, 338 (1979); Hunt v. Washington Apple Advertising Comm'n, 432 U.S. 333, 353 (1977); Great Atl. \& Pac. Tea Co. v. Cottrell, 424 U.S. 366, 375 (1976); Toomer v. Witsell, 334 U.S. 385, 406 n.41 (1948).

167. E.g., Lewis v. BT Inv. Managers, 447 U.S. 27, 43 (1980); Hughes v. Oklahoma, 441 U.S. 322, 338 (1979); Hunt v. Washington Apple Advertising Comm'n, 432 U.S. 333, 354 (1977); Great Atl. \& Pac. Tea Co. v. Cottrell, 424 U.S. 366, 377; Dean Milk Co. v. City of Madison, 340 U.S. 349, 354, 356 (1951); Baldwin v. G.A.F. Seelig, Inc., 294 U.S. 511, 524.

168. E.g., Raymond Motor Transp., Inc. v. Rice, 434 U.S. 429, 443 (1978); Bibb v. Navajo Freight Lines, 359 U.S. 520, 523 (1959); Terminal R.R. Ass'n v. Brotherhood of R.R. Trainmen, 318 U.S. 1, 8 (1943); South Carolina Highway Dep't v. Barnwell Bros., 303 U.S. 177, 187-90 (1938). 
ful milk, air, and water. ${ }^{169}$ Over the years, the Court also has recognized other noneconomic interests as clearly legitimate. These include racial equality, ${ }^{170}$ household privacy, ${ }^{171}$ and protection of natural resources. ${ }^{172}$ Presunably, the Court would treat all other conventional noneconomic interests as similarly legitimate.

On the other hand, the Supreme Court occasionally has suggested that state economic interests are not legitimate. For example, im his often quoted opinion for the Court in H.P. Hood \& Sons v. Du Mond, ${ }^{173}$ Justice Jackson repeatedly insisted that:

This distinction between the power of the State to shelter its people from menaces to their health or safety and from fraud, even when those dangers emanate from interstate commerce, and its lack of power to retard, burden or constrict the flow of such commerce for their economic advantage, is one deeply rooted in both our history and our law .... This Court consistently has rebuffed attempts of states to advance their own commercial interests by curtailing the inovement of articles of commerce ... while generally supporting their right to impose even burdensome regulations in the interest of local health and safety. ${ }^{174}$

Yet in cases involving both discriminatory and nondiscriminatory regulations, the Supreme Court frequently has recognized even some economic interests as legitimate. States may protect consumers from conventionally disfavored economic disadvantages such as fraud and overreaching, confusion, and mcompetent or inadequately insured sellers. ${ }^{175}$ More to the poimt, they may also protect consumers from high prices per se. ${ }^{176}$ They may use their regulatory power to protect taxpayers from excessive government costs. ${ }^{177}$ They may promote the economic welfare of producers by measures consistent with competition, as by enhancing the desirability of goods. ${ }^{178}$ Most conclusive of all, states may curtail competition to favor producers in relation to other producers or even to consumers. On at least three occasions in the current era, the

169. E.g., Sporhase v. Nebraska ex rel. Douglas, 458 U.S. 941, 956 (1982); Huron Portland Cement Co. v. City of Detroit, 362 U.S. 440, 442 (1960); Dean Milk Co. v. City of Madison, 340 U.S. 349, 353 (1951).

170. Bob-Lo Excursion Co. v. Michigan, 333 U.S. 28, 40 (1948).

171. Breard v. City of Alexandria, 341 U.S. 622,640 (1951).

172. E.g., Minnesota v. Clover Leaf Creamery Co., 449 U.S. 456, 471 (1981); Hughes v. Oklahoma, 441 U.S. 322, 336 (1979).

173. 336 U.S. 525 (1949).

174. Id. at 533, 535 .

175. E.g., Edgar v. MITE Corp., 457 U.S. 624, 644 (1982); Hunt v. Washington Apple Advertising Comm'n, 432 U.S. 333, 353 (1977); Robertson v. California, 328 U.S. 440, 447, 457 (1946); California v. Thompson, 313 U.S. 109, 114-15 (1941).

176. E.g., City of Philadelphia v. New Jersey, 437 U.S. 617, 626 (1978); Panhandle E. Pipe Line Co. v. Michigan Pub. Serv. Comm'n, 341 U.S. 329, 334 (1951).

177. See, e.g., Philadelphia, 437 U.S. at 627; Dean Milk Co. v. City of Madison, 340 U.S. 349, 355 (1951); South Carolina Highway Dep't v. Barnwell Bros., 303 U.S. 177, 187, 196 (1938).

178. Pike v. Bruce Church, Inc., 397 U.S. 137, 143 (1970). 
Supreme Court has upheld minimum price-fixing or its equivalent as applied to interstate commerce. ${ }^{179}$ Well may the Court have observed in City of Philadelphia v. New Jersey ${ }^{180}$ that "we assume New Jersey has every right to protect its residents' pocketbooks as well as their environment." 181

The Supreme Court does not require that the state's interest also be compelling or even important. Occasionally, however, the Court has suggested that health and safety are weightier than other legitimate state interests and thus might more readily justify a discriminatory regulation. For example, in Sporhase v. Nebraska ex rel. Douglas, ${ }^{182}$ it remarked that "a State's power to regulate the use of water . . . for the purpose of protecting the health of its citizens-and not simply the health of its economy-is at the core of its pohice power." ${ }^{183}$ At other times the Court has implied that other state interests, even economic ones, are equally weighty. Thus, in Lewis v. BT Investment Managers, Inc., it observed that "sound financial institutions and honest financial practices are essential to the health of any State's economy and to the well-being of its people" and thus "are of profound local concern."184

\section{Illegitimate Interests}

The Supreme Court so far has treated only one kind of state interest in a discriminatory regulation as wholly illegitimate. That is the interest of giving those within the state an economic advantage against people elsewhere. Justice Cardozo introduced this rule in Baldwin v. G.A.F. Seelig, Inc., ${ }^{185}$ when he condemned as illegitimate the aim to "suppress or mitigate the consequences of competition between the states," to establish "an economic barrier agamst competition with the products of another state or the labor of its residents." 186 Ordinarily those burdened are out-of-state producers seeking to sell their goods within the state in competition with local producers, as in Baldwin. ${ }^{187}$ But the prohibition

179. Cities Serv. Gas Co. v. Peerless Oil \& Gas Co., 340 U.S. 179 (1950); Parker v. Brown, 317 U.S. 341 (1943); Milk Control Board v. Eisenberg Farm Prods., 306 U.S. 346 (1939).

180. 437 U.S. 617 (1978).

181. Id. at 626 .

182. 458 U.S. 941 (1982).

183. Id. at 956. Likewise, in Raymond Motor Transp., Inc. v. Rice, 434 U.S. 429, 443 (1978), the Court asserted, "In no field has . . . deference to state regulation been greater than that of highway safety regulation."

184. 447 U.S. 27, 38 (1980). So too, in Hughes v. Oklahoma, 441 U.S. 322,337 (1979), the Court stated, "We consider the States' interests in conservation and protection of wild animals as legitimate local purposes similar to the States' interests in protecting the health and safety of their citizens."

185. 294 U.S. 511 (1935).

186. Id. at $522,527$.

187. See also Great Atl. \& Pac. Tea Co. v. Cottrell, 424 U.S. 366 (1976); Polar lce Cream \& Creamery Co. v. Andrews, 375 U.S. 361 (1964). 
also has been apphed to restrictions on exports calculated to give an advantage to local consumers. ${ }^{188}$

Most striking of all are the cases in which states have restricted the importation of people or articles thought burdensome. In Edwards v. California, ${ }^{189}$ arising during the Great Depression, Cahfornia had forbidden bringing indigent nonresidents into the state. It acknowledged that its main interest was to advantage local taxpayers, but it defended this interest on the ground that as long it bore the economic burden of dealing with its own indigents, it should have no duty to pay for the indigents of other states. The Supreme Court rejected this justification, asserting that of the limits on state regulatory power, "none is more certain than the prohibition against attempts on the part of any single State to isolate itself from difficulties common to all of thein by restraming the transportation of persons and property across its borders."190 Much more recently, New Jersey prohibited the importation for disposal within the state of most garbage generated elsewhere. The Court used almost the saine words in finding illegitimate the state's interest in City of Philadelphia v. New Jersey. ${ }^{191}$

In some cases problems may arise in determining whether the state's interest is the illegitimate one of gaining an economic advantage for its residents. First, the parties may disagree about whether the state's purported interest in accomplishing some other objective is genuine or a pretext. Typically, however, the Supreme Court treats such disagreements as bearing instead on whether the state's "purpose" is discriminatory, a matter discussed later. ${ }^{192}$ The legitimacy of the state's "interest" is deternined according to what the state avows; interests are found to be illegitimate only when the state, in the Court's words, "artlessly discloses" the ain of favoring its own people economically. ${ }^{193}$

Second, the state may have several genuine interests, including the objective of gaining an economic advantage for its residents, and the parties may disagree over which is decisive. For example, when New Jersey enacted the statute forbidding the importation for disposal of most garbage generated elsewhere, the state claimed that its interest was to conserve scarce open space and to curb pollution. The question remained why it had imposed a heavier burden on garbage producers outside the state. The only plausible answer was that it wished to give local garbage producers an advantage in the competition for limited disposal sites.

188. New England Power Co. v. New Hampshire, 455 U.S. 331 (1982); H.P. Hood \& Sons v. Du Mond, 336 U.S. 525 (1949).

189. 314 U.S. 160,173 (1941).

190. Id. at 173 .

191. 437 U.S. 617,628 (1978).

192. See infra text accompanying notes 223-33.

193. Dean Milk Co. v. City of Madison, 340 U.S. 349, 354 (1951). 
This might have been characterized as a situation in which the state's primary interest was legitimate but its secondary interest illegitimate. The Supreme Court preferred to think of it as an example of an illegitimate means to a legitmiate end. In any event, in City of Philadelphia v. New Jersey the Court invalidated the statute, declaring unequivocally that "the evil of protectionism can reside in legislative means as well as legislative ends." 194 In other words, even when the end or primary interest is legitimate, if the ineans or secondary interest is curtailing competition by those outside the state, the latter invalidates the whole. ${ }^{195}$

\section{B. Substantial Utility}

Not only must the state have a legitimate interest, its regulation inust be substantially related to that interest. In other words, the regulation must serve the interest to a substantial extent. Unless the legislature is peculiarly inept, state regulations ought to satisfy this test fairly readily.

Regulations are most likely to be found insufficiently related to state interests when the interests alleged may be specious. For example, in Hunt v. Washington Apple Advertising Commission, ${ }^{196}$ the North Carolina statute prevented Washington apple producers from using their own highly publicized grading system. The regulation may well have been intended to procure a coinpetitive advantage for local producers. The Suprenie Court, however, was prepared to assume that the state's alleged interest in preventing consumer confusion and deception was genuine but then concluded that the statute did not serve this interest substantially. For one thing, the statute only governed closed cartons of apples, and these were seen predominantly by apple dealers, not by consumers. The Court added that the former presumably are more knowledgeable than the latter, implying that they are not likely to be confused or deceived in any event. ${ }^{197}$

194. 437 U.S. at 626.

195. This is true even when the primary state interest is ostensibly health or safety. In the two New York milk cases, the state avowed the ultimate purpose of assuring an ample local supply of milk. Nevertheless, the Supreme Court held that it is illegitimate for a state to seek this end by curtailing either sales by out-of-state producers or purchases for out-of-state consumers. H.P. Hood \& Sons v. Du Mond, 336 U.S. 525, 538 (1949); Baldwin v. G.A.F. Seelig, Inc. 294 U.S. 511, 523 (1935).

The parties might also disagree about whether to characterize the state's conceded interest as giving local inhabitants an economic advantage or an advantage of another kind. For example, in Hood, the state allegedly sought to retain local milk supplies needed by local consumers. Some might characterize the state's interest as the physical nourishment of its residents. Justice Jackson dismissed the interest as economic. Hood, 336 U.S. at 531, 539.

196. 432 U.S. 333 (1977).

197. Id. at $352-53$. 


\section{Available Alternatives}

In the leading case of Dean Milk Co. $v$. City of Madison, ${ }^{198}$ the Supreme Court first announced the rule that "even in the exercise of its unquestioned power to protect the health and safety of its people," a state or locality may not discriminate against interstate commerce "if reasonable nondiscriminatory alternatives, adequate to conserve legitimate local interests, are available." ${ }^{199}$ In varying terms, the Court has often reiterated the rule since. ${ }^{200}$

Insofar as the Supreme Court has elaborated this requirement, it has done so somewhat strictly. Occasionally the Court has stated that a state regulation is invahid even if the alternatives are merely "less" discriminatory. ${ }^{201}$ Dean Milk itself may exeinplify this proposition. The city had forbidden the sale of milk not pasteurized within five miles of the city center. It claimed that the regulation served a health interest by facilitating inspection of pasteurizing plants. The Court reponded in part that the city might send its imspectors further afield and pass the additional inspection costs on to the pasteurizers. ${ }^{202}$ The alternative still put a heavier burden on out-of-state pasteurizers, but less so than the existing regulation.

Moreover, although the Supreme Court has suggested that it will not invalidate a regulation unless the alternatives do not serve the state interest fully "as well,",203 it may have withdrawn this concession in Hunt v. Washington Apple Advertising Commission. ${ }^{204}$ There the Court acknowledged that one of its proposed alternatives was not entirely effective in achieving the state's interest, to prevent deception and confusion of local apple consumers. It concluded, however, that the commerce clause required the sacrifice. ${ }^{205}$

The Supreme Court suggested an explanation of the condition that the alternatives be "reasonable" in Dean Milk itself. To the suggested alternative that the city send its inspectors further afield, the city apparently objected that the program would be excessively costly. The Court responded that this alternative was reasonable because the city inight pass inspection costs on to the pasteurizers. ${ }^{206}$ This suggests that a rea-

198. 340 U.S. 349 (1951).

199. Id. at 354 .

200. Indeed, the Court may have anticipated the rule long before Dean Milk, in Baldwin v.

G.A.F. Seelig, Inc., 294 U.S. 511, 523-24 (1935).

201. See Great Atl. \& Pac. Tea Co. v. Cottrell, 424 U.S. 366, 373 (1976).

202. Dean Milk, 340 U.S. at 355.

203. Hughes v. Oklahoma, 441 U.S. 322, 336 (1979).

204. 432 U.S. 333 (1977).

205. Id. at 354.

206. Dean Milk, 340 U.S. at 355. 
sonable alternative is one that does not unduly impair other legitimate state interests, such as saving the money of local taxpayers.

Recently, the Supreme Court has begun insisting that there must be a "close fit" between the geographical scope of the regulation and the need that allegedly justifies it. ${ }^{207}$ That is, the regulation may be neither unduly underinclusive in burdening local residents nor unduly overinclusive in relation to people elsewhere. This proposition may be understood as a partial restatement of the requirements just described. If a regulation is unduly underinclusive in burdening local residents, it may not serve the state's avowed interest to a substantial extent, and the state presumably has the less discriminatory alternative of expanding the scope of the regulation. Likewise, if the regulation is unduly overinclusive in relation to people elsewhere, the state can presumably narrow its scope without sacrificm the alleged imterest.

\section{Congressional Consent}

To all of these propositions there is one overriding exception. A discriminatory state regulation not justified by a sufficient state interest is nevertheless valid if Congress consents to the regulation. The leading case is Prudential Insurance Co. v. Benjamin, ${ }^{208}$ in which South Carolina had imposed a gross receipts tax on out-of-state insurance companies but not on local ones. Although the Supreme Court assuined for the sake of argument that the tax was discriminatory, it never appraised the justifications for the discrimination. Instead it interpreted the McCarran Act of $1945^{209}$ as having been intended to vahidate the tax, which foreclosed further argument under the commerce clause. ${ }^{210}$

For the first time last term, the Supreme Court applied this holding to a state regulation. Congress had forbidden holding coinpanies to acquire banks located in other states unless the acquisition was authorized by those states. Two New England states authorized such acquisitions but limited them to holding companies located in other New England states. In Northeast Bancorp, Inc. v. Board of Governors, ${ }^{211}$ the Court upheld the state regulations, asserting that in the absence of the congressional statute they would be invalid, but that "when Congress so chooses, state actions which it plainly authorizes are invulnerable to con-

207. Sporhase v. Nebraska ex rel. Douglas, 458 U.S. 941,957 (1982).

208. 328 U.S. 408 (1946).

209. The McCarran-Ferguson Act, 59 Stat. 33 (1945) (codified as amended at 15 U.S.C. $\S \S 1011-1015$ (1982 \& Supp. I 1983)).

210. Prudential, 328 U.S. at 427-33. In Metropolitan Life Ins. Co. v. Ward, 105 S. Ct. 1676 (1985), however, the Court held that the McCarran Act does not protect a state tax discriminating against out-of-state insurance companies from a challenge under the equal protection clause.

211. 105 S. Ct. 2545 (1985). 
stitutional attack under the Commerce Clause."212

At the same time, in several of its recent decisions, the Supreme Court has asserted that it will not find congressional consent to discriminatory state regulations unless the permission is "expressly stated" or otherwise "unmistakably clear." "The fact that the state policy . . . appears to be consistent with federal policy-or even that state policy furthers the goals ... that Congress had in mind-is an insufficient indicium of congressional intent."213 This suggests that the Court will be reluctant to hold that Congress has authorized discriminatory state regulations.

\section{IV}

\section{TYPES OF DISCRIMINATION}

In the preceding part, we discussed the normal burden that a state must bear to justify a discrimination agamst interstate commerce. To be quite accurate, however, it is necessary to distinguish between three types of discrimination-on the face of the regulation, $m$ its purpose, and in its effect. In Section $B$, I will show that the normal burden applies, more or less strictly, to discriminations on the face and to discriminations in effect that the Supreme Court suspects are discrimmatory in purpose. On the other hand, the Court conclusively presumes outright discriminations in purpose to be invalid, while discriminations in effect may not even be subject to a rebuttable presumption of invalidity when there is no substantial reason to suspect that they are also discriminatory in purpose.

Before considering these matters, I will examine the problems of identifying the three types of discrimination and the combinations in whicli they are likely to occur. I will also show that a regulation is more likely to be characterized as a discrimination of some kind if it is discriminatory $\mathrm{m}$ purpose or on the face than if it is solely in effect.

\section{A. Definition of the Types}

\section{On Face}

When a regulation is discriminatory on its face, the very terins of the regulation deal unequally with people inside and outside the state. There is no need to resort to any additional information-except perhaps matters known to practically everyone-to discern that the state has given an advantage to insiders. ${ }^{214}$

212. Id. at 2554; see also Sporhase v. Nebraska ex rel. Douglas, 458 U.S. 941, 958-60 (1982); New England Power Co. v. New Hampshire, 455 U.S. 331, 340-44 (1982); Lewis v. BT Inv. Managers, 447 U.S. 27, $44-49$ (1980); Polar Ice Cream \& Creamery Co. v. Andrews, 375 U.S. 361, 379 (1964); H.P. Hood \& Sons v. Du Mond, 336 U.S. 525, 540-45 (1949).

213. South Central-Timber Dev., Inc. v. Wunnicke, 104 S. Ct. 2237, 2246-47 (1984).

214. For example, Oklahoma had a statute that provided, with certain exceptions, " No person 
One might suppose that there would be no substantial difficulty in identifying a discrimination on the face of a regulation, and in most cases that is true. However, a few cases have turned up potentially significant difficulties that are worth considering.

First, as was described before, the city of Madison once had a regulation that forbade the sale of milk not pasteurized within five miles of the city center. In Dean Milk Co. v. City of Madison, ${ }^{215}$ the Supreme Court did not treat the regulation as discriminatory on its face, but only in effect. ${ }^{216}$ That the regulation also burdened pasteurizers elsewhere within the state does not account for this approach; if the distribution of burdens was sufficiently unequal to constitute a discrimination in effect, spelling out the unequal distribution on the face of the regulation would have made it that much more clearly discriminatory. Rather, the Court may not have considered the ordinance discriminatory on its face because a person would have to consult an atlas to detect the inequality. Otherwise, for all that person knew, Madison could be adjacent to the state line, with a substantial number of pasteurizers just across the border. In that case, there might be as many people advantaged by the regulation outside the state as within.

If this explanation of the decision is correct, it suggests that discrimination on the face is a matter of degree. The actual location of Madison is widely known or very readily determined. The Supreme Court might have held the regulation to be so close to a simple discrimination on the face as to deserve the same treatment. Apparently the Court prefers to avoid making mice judgments about the extent to which information not contained in the very terms of the regulation is a matter of common knowledge. At most, it will only take additional account of matters known to practically everyone.

A second potential difficulty in identifying discrimination on the face of a regulation relates to a certain kind of reciprocity requirement. Within less than a decade, the Supreme Court has ruled twice on regulations that permitted the import or export of certain goods only from or to states that permitted the import or export of those goods in return. For example, Mississippi had a regulation providing, "Milk and milk products from ... [another state] may be sold in . . . Mississippi ... provided ... that the [other state] accepts Grade A milk and milk products pro-

may transport or ship minnows for sale outside the state which were seined or procured within the waters of this state... ." Hughes v. Oklahoma, 441 U.S. 322, 323 (1979) (quoting Okla. Stat., Title 29, §4-115 (B) (Supp. 1978)). The very terms of the statute put out-of-state buyers of Oklahoma minnows at a disadvantage relative to local buyers.

215. 340 U.S. 349 (1951).

216. Id. at $353-54$. 
duced and processed in Mississippi on a reciprocal basis."217 In Great Atlantic \& Pacific Tea Co. v. Cottrell, ${ }^{218}$ the Court did not characterize the regulation as a discrimination on its face; indeed, although the Court treated it like a discrimination in effect, the opinion never used the words "discrimination" or even "protectionisin." 219 In a inore recent case, however, the Court concluded, "The reciprocity requirennent does not survive the 'strictest scrutiny' reserved for facially discriminatory legislation."220

If these reciprocity requirements are discriminatory on their face, they are an unusual instance of the type. They are not necessarily discriminatory in purpose within the definition proposed shortly; ${ }^{221}$ a state inay enact legislation requiring reciprocity with the genuine intention that other states will satisfy the requirenient and thereby eliminate the difference in treatinent between those outside and inside the state. Moreover, to the extent that this purpose is actually achieved, the requirements are not discriminatory in effect either.

In any event, the Supreme Court clearly was right in the Mississippi case when it observed that not all reciprocity requirements are discriminatory. ${ }^{222}$ Such legislation nray give other states the alternative of enjoying exentption from the prevailing nondiscriminatory burdens if they act reciprocally. For example, Mississippi might instead have allowed Louisiana producers whose imilk satisfied Louisiana requirements to sell their milk in Mississippi without also passing Mississippi tests, so long as Louisiana granted Mississippi producers a corresponding privilege. In such an event, the worst that may befall people outside the state is to be subjected to the same burdens as those within.

\section{In Purpose}

A regulation discriminates in purpose if its very object is to give those within the state an economic advantage by putting heavier burdens on people elsewhere. When coninientators speak of the "object" or "purpose" of a regulation, however, they may have different nreanings in mind. Sorne nray niean the objective function of the regulation. When the Supreme Court speaks of a discriminatory purpose, it seems to be thinking instead of the subjective intentions of the lawmakers. ${ }^{223}$

217. Great Atl. \& Pac. Tea Co. v. Cottrell, 424 U.S. 366, 367 (1976) (quoting $\S 11$ of Mississippi's Regulation Governing the Production and Sale of Milk and Milk Products).

218. 424 U.S. 366 (1976).

219. Id. at 375.

220. Sporhose v. Nebraska ex rel. Douglas, 458 U.S. 941, 958 (1982).

221. See infra text accompanying note 224.

222. Great Atl. \& Pac., 424 U.S. at 378.

223. See, e.g., Minnesota v. Clover Leaf Creamery Co., 449 U.S. 456, 463 n.7, 471 n.15 (1981); Hunt v. Washington Apple Advertising Comm'n, 432 U.S. 333, 352 (1977). 
Accordingly, a regulation is discriminatory in purpose if those who enacted it intended to give people within the state an economic advantage over people outside. ${ }^{224}$

The identification of discriminations in purpose is a hard and recurring problem. As I will show below, regulations that are discriminatory in purpose are per se invalid, ${ }^{225}$ which means that challengers have a strong incentive to assert the claim of purposeful discrimination whenever they can, and states generally have an equal incentive to deny it. Dean Ely asserts that these claims, when contested, are unusually difficult and delicate for courts to determme. ${ }^{226}$

Perhaps for these reasons the Supreme Court purports to give a strong presumption of authenticity to the purpose claimed by those who enacted the regulation. ${ }^{227}$ Moreover, in practice it has invalidated regulations as discriminatory in purpose only when the regulators at least partially acknowledged their intentions, perhaps supposing that the Court would not condemn them. ${ }^{228}$ Whenever the issue is contested and the Court can invalidate the regulation on an alternative ground, it withholds judgment on the issue of discriminatory purpose. ${ }^{229}$

Hunt v. Washington Apple Advertising Commission ${ }^{230}$ exemplifies the problematic character of this issue and the Supreme Court's way of disposing of it. A North Carolina regulation forbade the sale of apples in closed cartons bearing nonfederal grades. Washington producers claimed that the purpose of the regulation was to deprive thein of the competitive advantage afforded by their own grading system. The state

224. For example, in Hood, New York forbade an out-of-state milk distributor to set up a new plant to receive milk for sale outside the state. The state justified its action in part on the ground that the new plant would deprive local customers of existing milk supplies. The Supreme Court may have rcad the record as establishing that the state would not have given the same protection to existing customers in other states. See supra text accompanying notes 153-54. Under this view, the regulation was discriminatory in purpose as administered. It was intended to give local milk drinkers an advantage over their counterparts elsewhere.

225. See infra text accompanying notes $244-49$.

226. Ely, Legislative and Administrative Motivation in Constitutional Law, 79 YALE L.J. 1205, 1212-21 (1970). But see Brest, Palmer v. Thompson: An Approach to the Problem of Unconstitutional Legislative Motive, 1971 Sup. CT. REv. 95, 119-30.

227. Cf. Minnesota v. Clover Leaf Creamery Co., 449 U.S. 456, 463 n.7, 471 n.15 (1981) (holding that for commerce clause purposes, as in equal protection analysis, the "Court will assume that the objectives articulated by the legislature are actual purposes of the statute unless an examination of the circumstances forces us to conclude that they 'could not have been a goal of the legislation." Id. at 463 n.7 (quoting Weinberger v. Weisenfeld, 420 U.S. 636, 648 n.16 (1975)). Indeed, in Breard v. Alexandria, 341 U.S. 622, 636 n.20, 639 (1951), the Court may have disclaimed all responsibility for probing the state's alleged purposes. In this as in other ways, the opinion in Breard is out of line with the Court's presently prevailing doctrine.

228. E.g., New England Power Co. v. New Hampshire, 455 U.S. 331, 339 (1982); H.P. Hood \& Sons v. Du Mond, 336 U.S. 525, 530-31 (1949).

229. E.g., Lewis v. BT Inv. Managers, 447 U.S. 27, 31-32, 39, 42-44 (1980); Huut v. Washington Apple Advertising Comm'n, 432 U.S. 333, 352-54 (1977).

230. 432 U.S. 333 (1977). 
responded that its purpose instead was to protect consumers froin confusion and deception. The Court weighed these arguments and was nearly persuaded that the regulation discriminated in purpose by evidence that North Carolina apple producers " 'were mainly responsible for this legislation being passed." "231 But this evidence, like the evidence in most other cases of discrimination in effect, was inadequate to prove purposeful discrimination. Among other things, its force depended on the assuinption that producers rarely if ever find it in their own interests to take the lead in asserting the interests of tlieir custoiners, an assumption that inost of the Justices would not openly avow. Perliaps for this reason, the Court finally left the issue unresolved and invalidated the regulation on the ground that it was an unjustified discrimination in effect. ${ }^{232}$

The other evidence of discriminatory purpose cited by the Supreine Court in Hunt inay have been more probative. The Court found it "soinewhat suspect" that the regulation applied only to closed cartons. These are ordinarily seen by distributors, not consumers, yet the regulation supposedly protected the latter rather than the former. ${ }^{233}$ To put the point inore generally, it was evidence of a discriminatory purpose that the regulation did not serve the alleged state interest to a substantial extent. In other cases the saine conclusion inight be inferred from the fact that nondiscriminatory alternatives are readily available.

\section{In Effect}

A regulation is discriminatory in effect, regardless of whether it discrininates on its face or in purpose, if it has the effect of putting greater burdens on those outside tlie state, giving an advantage to local inhabitants. For exainple, im Hunt the Supreine Court clamied that the regulation made Washington producers change their labeling practices for apples sold in Nortl Carolina, a costly procedure. More inportant, it deprived them of the coinpetitive benefit of using their own well-publicized grading systein. Local producers, on the other hand, could continue their existing practices, since they did not use grades of their own. Thus the regulation constituted a discrinination in effect; it burdened those outside the state while leaving their competitors inside the state untouched. ${ }^{234}$

The Supreine Court is probably less ready to characterize a regulation as a discrimination of any kind if the alleged discrimination is solely in effect than if it is discriminatory on the face or in purpose. There are

231. Id. at 352 (quoting statement of the North Carolina Agriculture Commissioner).

232. Id. at $353-54$.

233. Id. at 352 .

234. Id. at 351-52. 
no holdings squarely on point, but inportant precedents point in this direction.

As noted before, the Supreme Court has suggested that certain types of burdens are insufficient to constitute a discrimination. ${ }^{235}$ The inost important of these cases dealt with regulations discriminating against out-of-state retailers of goods rather than the goods theinselves. ${ }^{236}$ Even if the Court adheres to this doctrine when the discriminations are in effect, it would probably take a different view of regulations discriminating against out-of-state retailers on their face or in purpose. Indeed, in a case decided shortly after Exxon Corp. v. Governor of Maryland, ${ }^{237}$ the Court tried to distinguish its prior decision on the ground that the Maryland regulation did not discriminate on its face..$^{238}$

The extent of mequality necessary to constitute a discrimination is, as noted before, a mice question of degree. ${ }^{239}$ For exainple, recall Minnesota v. Clover Leaf Creamery Co. ${ }^{240}$ All of the producers of raw inaterials burdened by the regulation were outside the state, yet the Supreine Court declined to treat it as discriminatory in effect. ${ }^{241}$ Before determining that the regulation did not put excessively unequal burdens on people outside the state, however, the Court took the trouble to assert that it was not discriminatory im purpose. ${ }^{242} \mathrm{Had}$ the Court found that the purpose of the regulation was to obtain an advantage for local producers, the case apparently would have been decided differently.

\section{Combinations of Types}

Regulations that belong to one type of discrimination are apt to belong to other types as well. Indeed, if a regulation is discriminatory on its face or in purpose, it is almost certain to be discriminatory in effect. Only a pecuharly inept legislature would enact a statute whose very terms purported to inpose a heavier burden on those outside the state, or whose purpose was to do so, but which failed to have that effect.

Nevertheless, many regulations discriminate in effect, and perhaps also in purpose, but not on their face. For example, the North Carolina apple regulation was not discriminatory on its face, but it discriminated in effect and was also suspected of discriminating in purpose.

Moreover, it is possible, though unlikely, for a regulation to discriminate on its face as well as in effect but not in purpose. For exainple, the

235. See supra text accompanying notes 58-82.

236. See supra text accompanying notes $64-82$.

237. 437 U.S. 117 (1978)

238. See Lewis, 447 U.S. at 42.

239. See supra text accompanying notes 83-99.

240. 449 U.S. 456 (1981).

241. Id. at 473 .

242. Id. at 471 . 
Supreme Court recently reaffirmed the validity of state quarantine regulations that on their face prohibit only the importation of certain plants or animals. ${ }^{243}$ Many of these regulations may have the ulterior purpose of giving producers within the state an advantage over those outside, but they need not. Like Great Britain in the case of rabies, a state may have virtually eradicated a disease within its borders, so that the purpose of the discrimination is merely to avoid unnecessary regulation of local activities.

\section{B. Significance of the Types}

\section{In Purpose}

In the leading case arguably concerning a discrimination in purpose as well as effect, H.P. Hood \& Sons v. Du Mond, ${ }^{244}$ the Supreme Court seems to have treated the state regulation as per se invalid. Justice Jackson described the regulation as having been "imposed for the avowed purpose and with the practical effect of curtailing the volume of interstate commerce to aid local economit interests ...."245 As noted before, Jackson asserted that all such regulations are invalid. ${ }^{246}$ Accordingly, the state was given no real opportunity to show a sufficient interest in the discrimination. ${ }^{247}$

The Supreme Court may have recently reaffirmed that discriminations in purpose are per se invalid. In New England Power Co. v. New Hampshire, a case concerning a regulation that was also discriminatory on its face, the Court stated, this "is precisely the sort of protectiomist regulation that the Commerce Clause declares off-limits to the states. The Commission has made clear that its order is designed to gam an economic advantage for [local] citizens at the expense of ... customers in neighboring states." 248 The Court did not bother to discuss any justifications that the state may have adduced. Moreover, in practice, the Court has never upheld a regulation identified as discriminatory in purpose during the current era. There are at least two tenable ways of understanding this rule. One is to suppose that discriminations in purpose are so harmful that no state interest, no matter how legitinate and substantial, can ever serve to justify them. In other words, the reasons that the Supreme Court disfavors state discriminations apply with overwhelming force to discriminations in purpose, while the contrary considerations hardly counteract them at all.

243. City of Philadelphia v. New Jersey, 437 U.S. 617, $628-29$ (1978).

244. 336 U.S. 525 (1949).

245. Id. at $530-31,535$.

246. See supra text accompanying note 174 .

247. Id. at 564 (dissenting opinion).

248. 455 U.S. 331 (1982). 
The other way of understanding a per se rule against discriminations in purpose is that they shift the same burden of justification to the state as other discriminations but that discriminatory purposes always constitute illegitimate state interests. The definitions of discriminatory purpose and of illegitimate interest proposed in this Article are closely akin-to obtain an economic advantage for local residents over outsiders. Once the Suprense Court has gone behind a state's allegations to find a discriniinatory purpose, it need do no more to conclude that the state's actual interest is illegitimate.

\section{On Face}

In recent cases, the Suprenie Court also has begun to assert that discriminations on the face of a regulation, although not in purpose, are disfavored nearly as strongly as discriminations in purpose. The former are not necessarily invahd per se, but the burden of justification on the state is always especially heavy. Thus, in Hughes $v$. Oklahoma, ${ }^{249}$ the Court noted that the regulation "on its face discrininates against interstate commerce. . . . Such facial discrimination by itself niay be a fatal defect, regardless of the State's purpose . . . . At a minimun such facial discrimination invokes the strictest scrutiny [of the state interest]."250 In practice, during the current period, the Court has never held a discrinination on the face to be justified, except in dicta. ${ }^{251}$

Again, there are two tenable ways of understanding this rule. One is to suppose that discriminations on the face, even when not in purpose as well, are so harmful that hardly any state interest will be sufficient to justify them. In other words, the reasons that the Suprenie Court disfavors state discriminations apply forcefully to regulations discriminatory on their face, while the contrary considerations are of relatively little account.

The other way of understanding the rule that discriminations on the face are nearly per se invalid is to suppose that they are likely to be purposeful as well. If a state's purposes are not discriminatory, it rarely has a strong reason to discrininate on the face of its regulations against those outside the state. For example, in Lewis v. BT Investment Managers, Inc. ${ }^{252}$ the state sought to justify a regulation forbidding ownership of local investnent businesses by certain out-of-state companies in part on the ground of curtailing economic concentration. ${ }^{253}$ If that had been a

249. 441 U.S. 322 (1979).

250. Id. at $336-37$.

251. See Sporhase v. Nebraska ex rel. Douglas, 458 U.S. 941, 958 (1982); City of Philadelphia v. New Jersey, 437 U.S. 617, 628 (1978).

252. 447 U.S. 27 (1980).

253. Id. at $42-43$. 
genuine purpose, however, the state might rather have framed the regulation in terms of the size of the owning company, wherever located. In such a case, the rule shifts an especially heavy burden to the state to prove that its purposes are not discriminatory by showing a legitimate and substantial interest in the regulation.

The opimions may bear out this understanding of the rule. In a number of cases in which the Supreme Court treated the regulation as discriminatory on its face and in effect, it suggested that the regulation may also have discriminated in purpose. ${ }^{254}$

There is an old line of decisions that is arguably inconsistent with the proposition that regulations discriminatory on their face are nearly per se invalid. In the very case that heralded the Suprene Court's current doctrine disfavormg state discriminations, Baldwin v. G.A.F. Seelig, Inc., ${ }^{255}$ the Court expressly reaffirmed its prior decisions that "a state may regulate the importation of unhealthy swine or cattle ... or decayed or noxious foods."256 The most recent of the decisions had been rendered only two years before Baldwin, unanimously upholding a New York regulation that forbade the importation of dairy and breeding cattle unless both the cattle and the herds from which they canne were proved to be free of Bang's disease. ${ }^{257}$ Just four years later, the Court upheld without dissent a related Indiana regulation that forbade disposal of certain dead ammals elsewhere than on the owner's premises or at disposal plants within the state. ${ }^{258}$

Most of these cases, if not all, seem at least to have involved discrimination on the face of the regulations. They were generally upheld, not because the states had an overwhelming justification for the regulations, but on the ground that the articles regulated were outside the scope of the commerce clause. As the Supreme Court restated the point in Baldwin, "Things such as these are not proper subjects of commerce, and there is no unreasonable interference when they are inspected and excluded." 259 This is one of those special doctrines, referred to in the introduction, ${ }^{260}$ that antedated the pervasive current dichotomy between discriminatory and nondiscriminatory state regulations.

Recently, however, the Supreme Court has taken a different view of the quarantine cases. In City of Philadelphia v. New Jersey, ${ }^{261}$ the lower court had relied on these precedents in upholding the state's power to

254. E.g., id. at 39; City of Philadelphia v. New Jersey, 437 U.S. 617, 629 (1978).

255. 294 U. S. 511,525 (1935).

256. Id. at 525 (citations omitted).

257. Mintz v. Baldwin, 289 U.S. 346 (1933).

258. Clason v. Indiana, 306 U.S. 439 (1939).

259. Baldwin, 294 U.S. at 525.

260. See supra text accompanying notes 4-7.

261. 437 U.S. 617 (1978). 
forbid importation of garbage generated outside the state. The Court responded, "All objects of interstate trade merit Commerce Clause protection; none is excluded by definition at the outset. In [the prior] cases, the Court held simply that because the articles' worth in interstate commerce was far outweighed by the dangers inhering in their very movement, States could prohibit their transportation across state lines." 262 Thus the Court now purports to apply the same rules to quarantines as to state regulations generally.

The Supreme Court's new explanation of the quarantine cases, however, is still problematic. The Court does not establish either that discriminating against interstate shipments served the states' interests to a substantial extent or that they lacked nondiscriminatory alternatives. In fact, if the importation of diseased animals or other undesirable articles is inherently dangerous, so is their existence entirely within the state. The quarantine regulations were seemingly underinclusive, and the states had the nondiscriminatory alternative of banning all transportation or possession of the undesirable articles.

The Supreme Court is in a familiar jurisprudential quandary regarding the quarantine cases. In the midst of moving from one doctrinal approach to another, it is prepared to abandon the reasoning of the old cases, but it is still attached to their holdings. The result is temporary incoherence.

Altering the doctrine of the quarantine cases need not require the Supreme Court to abandon their holdings altogether. For example, other regulations may have similarly restricted transportation or possession of the undesirable goods within the states, so that no discrimination actually resulted, or the states may have been able to prove that the evils threatened by importation of the goods did not presently exist within the state, so that the discrimination was justified.

By contrast, the process of abandoning another of the special doctrines that antedated the current approach is now coinplete. Nearly a century ago the Supreme Court adopted the rule that a state might forbid the export of certain of its natural resources even though privately owned. It reasoned that the state was in some sense also the owner of the resources, so that their disposition was outside the commerce clause. ${ }^{263}$ Then, in a series of decisions over a long period, the Court gradually abandoned this reasoning and disavowed certain applications of the doctrine. ${ }^{264}$ Finally, just five years ago the Court expressly rejected the doc-

262. Id. at 622 .

263. Hudson County Water Co. v. McCarter, 209 U.S. 349 (1908); Geer v. Connecticut, 161 U.S. 519 (1896).

264. E.g., Pennsylvania v. West Virginia, 262 U.S. 553 (1923); West v. Kansas Natural Gas Co., 221 U.S. 229 (1911). 
trine in favor of its general approach to discriminatory regulations. At the same time it acknowledged that the states have legitimate interests that might justify extensive regulation of their natural resources. ${ }^{265}$

\section{Unsettled Issue-In Effect}

Thus far, we have assumed that the state bears a heavy burden of justifying even regulations that are discriminatory solely in effect. This is a defensible assumption. The two leading cases in which the Supreme Court has struck down such regulations are Dean Milk Co. v. City of Madison ${ }^{266}$ and Hunt v. Washington Apple Advertising Commission. ${ }^{267}$ In Dean Milk, the Court announced for the first time that the state must show that it lacks nondiscriminatory alternatives in order to justify a discriminatory regulation. ${ }^{268}$ In Hunt, the Court again applied this requirement and also asked whether the regulation served the alleged state interest to a substantial extent. ${ }^{269}$ As noted before, these tests add up to a heavy doctrinal burden; in equal protection terms, they are characteristic of intermediate and perhaps even strict scrutiny.

Yet a closer look at these and several other cases suggests at least one alternative proposition. Perhaps the Supreme Court applies the rigorous requirements described in Part III only to certain discriminations in effect. The Court may take a rigorous approach when it has a substantial suspicion that the regulation is also discriminatory in purpose but lacks sufficient evidence to characterize it as such. Otherwise, discriminations in effect are measured by criteria that are hardly, if at all, stricter than those that apply to nondiscriminatory regulations. ${ }^{270}$

Dean Milk and Hunt give substantial support to this alternative reading. In both cases, the Supreme Court first raised the possibility that the regulations were discriminatory in purpose. In Dean Milk, the Court referred somewhat grudgingly to the "avowed" purpose of the regulation, and it later condemned the view that "the ordinance is valid simply because it professes to be a health measure," claiming that by that view, "the Commerce Clause of itself imposes no limitations on state action ... save for the rare instance where a state artlessly discloses an avowed purpose to discriminate against interstate goods."271 Likewise, in Hunt, the

265. See Hughes v. Oklahoma, 441 U.S. 322, 335-36 (1979). Dictum in Sporhase v. Nebraska ex rel. Douglas, 458 U.S. $941,956-57$ (1982) hints that the special doctrine relating to exportation of natural resources may not be wholly overruled.

266. 340 U.S. 349 (1951).

267. 432 U.S. 333 (1977).

268. 340 U.S. at $354-55$.

269. 432 U.S, at $353-54$.

270. Indeed, in Breard v. Alexandria, 341 U.S. 622, 638-39 (1951), the Court may have suggested that discriminations solely in effect are not discriminations at all. See id. at 647-48 (dissenting opinion). But see supra note 227.

271. 340 U.S. at 354. 
Court claimed that "there are some indications in the record" that the regulation is discriminatory in purpose, and it then recited the evidence, calling one item "the most glaring" and another "somewhat suspect."272

Two other cases may support the proposition that the Supreme Court applies a relatively lax test to discriminations in effect when the Court does not have substantial reason to suspect that the discrimination is also purposeful. The first of these is Brotherhood of Locomotive Firemen v. Chicago, Rock Island \& Pacific ${ }^{273}$ and its antecedent case. Arkansas had required that all railroads with track of more than a specified mileage withm the state carry a minimum crew for certain operations. It was conceded that because of the mileage requirement, all seventeen of the local railroads were exempt from the regulations, whereas a large majority of the interstate railroads were subject to them. Accordingly, the Supreme Court seems to have assumed that the regulations were discriminatory im effect. ${ }^{274}$ However, by a vote of seven to one the Court found the regulations sufficiently justified, the only time that it has done so in any of the discrimination cases in the current period. In its first decision, prior to trial, the Court stated the test to be whether the regulations had "any rational basis."275 After a full trial on the issue, the Court found this test to have been satisfied; it denied without rigorous discussion the availability of nondiscriminatory alternatives, strongly suggesting that in any event this is an improper criterion. ${ }^{276}$ Both rulings were inconsistent with the heavy burden that the Court purported to put on the states to justify the discriminations in effect in Dean Milk and Hunt. $^{277}$

The explanation may be that im the full-crew cases, the Court did not suspect that the discrimination was purposeful. It recited the state's justifications for the mileage requirement, one of which-shielding small railroads from heavy financial burdens-had nothing to do with safety and was frankly economic. ${ }^{278}$ Even this justification did not suggest a purpose of giving local businesses an advantage over their out-of-state counterparts. Perhaps for this reason the Court applied the laxer test appropriate to regulations that are nondiscriminatory.

The second case suggesting that the Supreme Court applies a rela-

272. 432 U.S. at 352 .

273. 393 U.S. 129 (1968).

274. See id. at 141 .

275. Brotherhood of Locomotive Eng'rs v. Chicago, R.I. \& Pac. R.R., 382 U.S. 423, 437 (1966).

276. Locomotive Firemen, 393 U.S. at 142.

277. Perhaps the reasoning of the full-crew cases should no longer be taken seriously. Just four years ago, a plurality of the Supreme Court stated that it still adhered to the second decision in result "although perhaps not in all of its language." Kassel v. Consolidated Freightways Corp., 450 U.S. 662,678 n.25 (1981) (plurality opinion).

278. Locomotive Firemen, 393 U.S. at 142. 
tively lax test of justification to certain discriminations in effect is Minnesota v. Clover Leaf Creamery $\mathrm{Co}^{279}$ As described previously, the state barred the retail sale of inilk in rigid plastic nonreturnable containers. $^{280}$ The Court conceded that the only producers of raw materials for milk containers burdened by the regulation were outsiders. However, the Court did not discuss the possibility that the regulation was discriminatory in effect. Rather, having established to its own satisfaction that the regulation was not discriminatory in purpose, it went on to apply a balancing test appropriate to nondiscrimination cases. ${ }^{281}$ It was in the course of this discussion that the Court conceded the effect of the regulation on out-of-state producers but found the effect to be justified. Its discussion of the availability of less burdensome alternatives was cursory to say the least. ${ }^{282}$

In short, in this case the Supreme Court seems not to have had a substantial suspicion that the regulation discriminated in purpose. Under the circumstances, it treated discriminatory effect merely as one aspect of the less rigorous inquiry appropriate to nondiscriminatory regulations.

If we consider this issue in the hight of the reasons that the Supreme Court gives for disfavoring state discriminations, it is doubtful that all discriminations in effect are sufficiently harmful to warrant imposing a heavy burden of justification on the states. For example, discriminations solely in effect may be substantially less likely to provoke retahiation by other states than discriminations that can be discerned on the face of the regulation or that are thought to be purposeful. In the words of Justice Holmes, "even a dog distinguishes between being stumbled over and being kicked."283

Likewise, we may not be justified in assuming that all discriminations in effect are likely to be purposeful as well. Recall, for example, the alternatives proposed by the Supreme Court to the regulation in Dean Milk. One involved charging out-of-state pasteurizers the additional cost of inspecting their plants. ${ }^{284}$ This alternative still constituted a discrimination in effect, yet obviously the Court did not desire that result.

At the same time, considerations of judicial competence may argue against going to the other extreme of imposing only a hight burden on the states to justify all discriminations in effect. Some of these regulations raise a substantial suspicion that they also discriminate in purpose, and

279. 449 U.S. 456 (1981).

280. See supra text accompanying notes $96-99$.

281. Cloverleaf, 449 U.S. at 471-73.

282. Id. at 473-74.

283. O.W. Holmes, THe COMMON LAW 3 (1881).

284. Dean Milk Co. v. City of Madison, 340 U.S. 349, 354-55 (1951). 
therefore the courts may not want to validate them routinely; that was certainly the case in Hunt. Yet as was noted before, to determine that a regulation actually discriminates in purpose may be an unusually delicate and difficult judicial task. Perhaps the best solution to this dilemma is for the courts to put a heavy burden on the states to justify those regulations about which they have a substantial suspicion. In the words of Dean Ely, strict scrutmy then "turns out to be a way of 'flushing out' unconstitutional motivation, one that lacks the proof problems of a more direct inquiry and into the bargam permits courts ... to be more politic ...."285

This line of analysis unay be simplified further. On the one hand, when the courts identify a discriminatory purpose, one important itein of evidence may be the fact that the regulation does not serve the state's alleged interest to a substantial extent or that nondiscriminatory alternatives are readily available. On the other hand, when the courts suspect a discriminatory purpose, they may put a heavy burden on the state to slow that the regulation does serve the state's interest substantially and that alternatives are not available. Perhaps it would be inore accurate simply to say that the Supreme Court puts a heavy burden on the state to justify a discrimination im effect when it suspects that the state cannot succeed.

\section{RESPONSE TO DISSENTERS}

The foregoing description of the law of state discriminations against interstate commerce is subject to at least one common objection. According to some students of the subject, instead of analyzing cases according to a structure of doctrine such as the one described, the Supreme Court decides them by an amorphous balancing process. That is, the Justices take all relevant circumstances into account and render judgment according to their overall sense of the advantages and disadvantages of upholding the regulation. ${ }^{286}$ Sucli a process inerges every stage of analysis in the case, from the deternination whether a regulation is discriminatory, through the allocation of the appropriate burden of justification, to the decision whether the state has met that burden. No issues are resolved by per se rules.

This view miglit be based partly on what the Supreme Court has said it is doing. The Court has avowed a balancing test in certain cases involving nondiscriminatory state regulations. The most renowned of these is Southern Pacific Co. v. Arizona; ${ }^{287}$ another contains an emphatic dictum by Justice Frankfurter to the effect that "[w]hatever may be the

285. J. Ely, supra note 32, at 146 (footnotes omitted); see generally id. at 145-48.

286. See infra notes $289-91$.

287. 325 U.S. 761 (1945). 
generalities to wlicli [the prior] cases gave utterance..., the fate of state legislation in these cases has not been determined by these generalities but by the weight of the circumstances and the practical and experienced judgment in applying these generahties to tlie particular instances."288 Leading commentators, including Professors Dowling and Gunther, liave urged application of a balancing test to discriminatory regulations as well. ${ }^{289}$ Perliaps in response to these urgings, some Justices have begun to talk of balancing in discrimination cases. For exainple, in an opinion for the Court, Justice Stewart cited Hunt v. Washington Apple Advertising Commission, a clear case of discrimination im effect, as an example of the "much inore flexible approach" of Pike v. Bruce Church, Inc. ${ }^{290}$ Likewise, in dissentimg opinions, Justices as far apart in viewpoint as Brennan and Rehnquist have advocated the "balancing approach" of Pike in judging state regulations tliat ostensibly discriminated. ${ }^{291}$

The claim that the Supreme Court lias hardly any doctrine other than an amorphous balancing test might also be based on the actual outcomes of cases. Arguably, even in the current era there has been a large number of decisions that do not fit the prior analysis. In most of these, the Court upheld regulations that might liave been invalidated as unjustified discriminations. They include the retailing cases-Panhandle Eastern Pipe Line Co. v. Michigan Public Service Commission, Breard v. City of Alexandria, and Exxon Corp. v. Governor of Maryland; ;92 $^{29}$ the minimum price cases-Parker v. Brown and Cities Service Gas Co. v. Peerless Oil \& Gas Co. ${ }^{293}$ tlie quarantme cases-Mintz v. Baldwin and Clason v. Indiana, ainong otliers; ${ }^{294}$ and the full-crew cases, especially Brotherhood of Locomotive Firemen v. Chicago, Rock Island \& Pacific Railroad ${ }^{295}$ In other cases-Baldwin v. G.A.F. Seelig, Inc., and H.P. Hood \& Sons v. Du $M o n d,{ }^{296}$ - the Court invalidated regulations as if they were discrininatory although they well may not liave been.

It is undeniable that there are eleinents of balancing in the doctrines

288. Union Brokerage Co. v. Jensen, 322 U.S. 202, 211 (1944). In a relatively recent case the Court quoted a nonjudicial writing by Frankfurter to the same effect: "[P]ractical considerations, however screened by doctrine, underlie resolution of conflicts between state and national power." Great Atl. \& Pac. Tca Co. v. Cottrell, 424 U.S. 366, 372 n.6 (1976). Curiously, Justice Frankfurter reverted to "principle," at the expense of "the particular," in Panhandle E. Pipe Line Co. v. Michigan Pub. Serv. Comm'n, 341 U.S. 329, 340 (1951) (dissenting opinion).

289. G. GUNTHER, supra note 4, at 297-341; Dowling, Interstate Commerce and State Power, 27

VA. L. REV. I, 16 (1940).

290. City of Philadelphia v. New Jersey, 437 U.S. 617, 624 (1978).

291. Hughes v. Alexandria Scrap Corp., 426 U.S. 794, 823 n.5 (1976) (Brennan, J., dissenting);

Hughes v. Oklahoma, 441 U.S. 322, 343 n.7 (1979) (Rehnquist, J., dissenting).

292. See supra text accompanying notes $64-82$.

293. Sec supra text accompanying notes $132-39$.

294. See supra text accompanying notes 255-62.

295. Sec supra text accompanying notes 273-78.

296. See supra text accompanying notes 144-56. 
previously described in this Article. At the most general level, even when a regulation is found to be discriminatory, the Supreme Court weighs the burdens of the discrimination against its benefits. The state may justify the discrimination by showing that it has a legitimate interest, that the regulation serves this interest to a substantial extent, and that there are no nondiscriminatory alternatives available. ${ }^{297}$ In at least one case during the current period, the state arguably proved its side of the balance to be more weighty. ${ }^{298}$

Moreover, im measuring the weights on each side, the Supreme Court may take individual circumstances into account, treating them somewhat as matters of degree. For example, there are cases suggesting that some types of economic restrictions may shift a heavier burden to the state than others, depending on how close the restrictions come to putting a total ban on imterstate commerce. ${ }^{299}$ Likewise, noneconomic state interests may more readily satisfy the burden than economic interests, and health and safety interests may do so most readily of all. ${ }^{300}$

However, the more far-reaching claim that in these cases the Supreme Court has hardly any doctrine other than an amorphous balancing test is ultimately unpersuasive. Over the past fifty years, the Court has repeatedly asserted that state discriminations against interstate commerce are strongly disfavored. For example, in an early case, Justice Stone wrote for the Court, "The Commerce Clause, by its own force, prohibits discrimination against interstate commerce, whatever its form or method . ...301 A dozen years later, by way of emphasizing the breadth of state power to affect interstate commerce, the Court remarked, "The only requirements consistently recognized have been that the regulation not discriminate against or place an embargo on interstate commerce ... and that the local interest at stake outweigh whatever national interest there might be in the prevention of state restrictions."302 Within the past decade, in the same opinion by Justice Stewart quoted before, the Court asserted that "where simple economic protectionism is effected by state legislation, a virtually per se rule of invalidity has been erected." 303 These sayings cannot be reconciled with the claim that dis-

297. See supra Part III.

298. Brotherhood of Locomotive Firemen \& Enginemen v. Chicago, R.I. \& Pac. R.R., 393 U.S. 129 (1968).

299. See supra text accompanying notes 58-81.

300. See supra text accompanying notes 168-84.

301. South Carolina Highway Dep't v. Barnwell Bros., 303 U.S. 177, 185 (1938).

302. Cities Serv. Gas Co. v. Peerless Oil \& Gas Co., 340 U.S. 179, 186-87 (1950) (emphasis added).

303. City of Philadelphia v. New Jersey, 437 U.S. 617, 624 (1978). In this passage, as in many others, "protectionism" is used by the Court as a rough equivalent of discrimination. 
criminatory and nondiscriminatory regulations are all judged by the same amorphous balancing test.

Indeed, over the years, certain Justices have suggested that the ouly state regulations affecting interstate commerce they would invalidate are those that discriminate. Foremost among these are Justices as diverse as Black, Douglas, and Rehnquist. ${ }^{304}$

Moreover, apart from the retailing cases, which are concededly aberrant, none of the Supreme Court's outcomes refute the prior analysis. The mimimum-price cases arguably rest on a tenable refinement of the basic discrimination doctrine, namely that it applies only to mequalities between economic counterparts. The quarantime cases are a dying remnant of a prior doctrinal era, when harmful goods comprised a special category. The outcome of the full-crew cases arguably rests on another tenable refinement, that the basic doctrine apphes to discriminations im effect ouly when there is substantial reason to suspect that they are also purposeful. As for Baldwin and Hood, the regulations in those cases may have been discriminatory within the definition adopted before. In any event, the prior analysis is not refuted by showing that another category of regulations, those involving anti competitive economic isolationism, are also strongly disfavored.

At the same time, at least a dozen Supreme Court decisions support the foregoing analysis in every essential way. In each of these cases the state regulation was discriminatory withm the proposed defimition, and the Supreme Court strongly disfavored it accordingly. What is more, in most of the cases the Court explicitly characterized the regulation as discriminatory or used an equivalent term. ${ }^{305}$ Nearly all of these decisions were rendered within the last decade, by which time the presently prevailing dichotomy between discriminatory and nondiscriminatory regulations had largely crystallized. In the rest of the cases, all that was lacking was explicit recoguition that the state regulation was discriminatory. ${ }^{306}$ Almost all of them were decided before the last decade, when the Supreme Court was still not fully aware of the doctrine that it liad been evolving. As late as 1976, the Court treated a reciprocity requirement as unfavorably as a discrimmation in effect but did not characterize it as

304. Cf. Kassel v. Consolidated Freightways Corp., 450 U.S. 662, 691-92 (1981) (Rehnquist, J., dissenting); H.P. Hood \& Sons v. Du Mond, 336 U.S. 525, 556-57 (1949) (Black, J., dissenting); Southern Pac. Co. v. Arizona ex rel. Sullivan, 325 U.S. 761, 795 (1945) (Douglas, J., dissenting).

305. See Sporhase v. Nebraska ex rel. Douglas, 458 U.S. 941 (1982); New England Power Co. v. New Hampshire, 455 U.S. 331 (1982); Lewis v. BT Inv. Managers, 447 U.S. 27 (1980); Hughes v. Oklahoma, 441 U.S. 322 (1979); City of Philadelphia v. New Jersey, 437 U.S. 617 (1978); Hunt v. Washington Apple Advertising Comm'n, 432 U.S. 333 (1977); Dean Milk Co. v. City of Madison, 340 U.S. 349 (1951).

306. See Great Atl. \& Pac. Tea Co. v. Cottrell, 424 U.S. 366 (1976); Pike v. Bruce Church, Inc., 397 U.S. 137 (1970); Polar Ice Cream \& Creamery Co. v. Andrews, 375 U.S. 361 (1964); Toomer v. Witsell, 334 U.S. 385 (1948); Edwards v. California, 314 U.S. 160 (1941). 
such; by 1982, it was prepared to call a similar regulation discriminatory on its face. ${ }^{307}$

In cases involvmg regulations not treated as discriminatory, the Supreme Court's doctrines are clearly more lenient than the ones described. In some of these, the Court has asserted that the state bears a relatively light burden of justification; it need only adduce some significant evidence that the regulation serves its interests to a substantial extent, and it allegedly has no burden whatever of demonstrating an absence of available alternatives. ${ }^{308}$ Even in those cases in which the state must make a somewhat stronger showing that the regulation is of substantial utility, the Court sometimes does not ask about the availability of alternatives or does so in a perfunctory way. ${ }^{309}$

Moreover, $m$ terms of outcomes, the Supreme Court clearly treats nondiscriminatory state regulations differently. Over the years it has upheld a large number of them even though they burdened interstate commerce. $^{310}$ In some of these cases the Court took the trouble to assert explicitly that the regulations were not discriminatory. ${ }^{311}$

The ultimate touchstone of these contentions may be Pike v. Bruce Church, Inc., ${ }^{312}$ probably the most often quoted recent case on state regulation of interstate commerce. Arizona forbade a producer to export its melons unless they were crated within the state according to state standards. At the least the regulation discriminated on its face against people outside the state who would otherwise have processed the melcns. According to the doctrines previously described, the Court should have placed on the state a heavy burden of justifying the regulation, including proof that it lacked nondiscriminatory alternatives. Had the Court done

307. Compare Great Atl. \& Pac. Tea Co. v Cottrell, 424 U.S. 366, 375-81 (1976) (characterizing the reciprocity clause as having "in practical effect exclude[d] from distribution in [Mississippi] wholesome milk produced . . . in [Louisiana]," id. at 375), with Sporhase v. Nebraska ex rel. Douglas, 458 U.S. 941, 958 (1982) (characterizing reciprocity requirement as "facially discriminatory legislation").

308. See Raymond Motor Transp. Inc. v. Rice, 434 U.S. 429, 444, $447-48$ (1978); Bibb v. Navajo Freight Lines, 359 U.S. 520, 524 (1959).

309. Minnesota v. Clover Leaf Creamery Co., 449 U.S. 456, $473-74$ (1981).

310. E.g., Minnesota v. Clover Leaf Creamery Co., 449 U.S. 456 (1981); Huron Portland Cement Co. v. City of Detroit, 362 U.S. 440 (1960); Cities Serv. Gas Co. v. Peerless Oil \& Gas Co., 340 U.S. 179 (1950); Bob-Lo Excursion Co. v. Michigan, 333 U.S. 28 (1948); Robertson v. California, 328 U.S. 440 (1946); Union Brokerage Co. v. Jensen, 322 U.S. 202 (1944); Parker v. Brown, 317 U.S. 341 (1943); California v. Thompson, 313 U.S. 109 (1941); Milk Control Bd. v. Eisenberg Farm Prods., 306 U.S. 346 (1939); South Carolina Highway Dep't v. Barnwell Bros., 303 U.S. 177 (1938).

311. E.g., Minnesota v. Clover Leaf Creamery Co., 449 U.S. 456, $471-72$ (1981); Huron Portland Cement Co. v. City of Detroit, 362 U.S. 440, 448 (1960); Cities Serv. Gas Co. v. Peerless Oil \& Gas Co. 340 U.S. 179, 188 (1950); Robertson v. California, 328 U.S. 440, 449 (1946); Parker v. Brown, 317 U.S. 341, 367 (1943); California v. Thompson, 313 U.S. 109, 112 (1941); South Carolina Highway Dep't v. Barnwell Bros., 303 U.S. 177, 189 (1938).

312. 397 U.S. 137 (1970). 
so, it should then have noticed that the case was akin to Dean Milk Co. v. City of Madison. ${ }^{313}$ The state interest was to enhance the reputation of local farm produce by assuring that the melons were crated properly and also by claiming credit for the high quality melons of the particular producer. This interest could have been adequately served by charging the producer the cost of inspection outside the state--and also by requiring the melons to be labeled "Grown im Arizona."

Instead the Supreme Court began its analysis with the often quoted dictum, declaring that "[w]here the statute regulates evenhandedly to effectuate a legitimate local public interest," the Court balances the local benefits and national burdens of the regulation. ${ }^{314}$ It then applied this balancing approach to the facts of the case. The Court assumed that the interest was legitimate but held it to be outweighed by the burden on the producer. ${ }^{315}$

Yet Pike supports our account of existing doctrine more than it refutes that account. After all, the Supreme Court began its often quoted dictum by suggesting that discriminatory regulations are judged by a method different from the balancing approach appropriate to nondiscriminatory regulations. Moreover, by the end of its argument it asserted that regulations requiring processing to be done within the state are virtually per se illegal, ${ }^{316}$ and it gave judginent against the state accordingly. As in other cases, some of the reasoning im Pike may be aberrant, but the rest of the reasoning, as well as the outcome, is in complete accord with the law of state discrimination against interstate commerce described im this Article.

313. 340 U.S. 349 (1951).

314. Pike, 397 U.S. at 142.

315. Id. at 142-46.

316. Id. at 145 . 
